\title{
Driving investments in ore beneficiation and scrap upgrading to meet an increased demand from the direct reduction-EAF route
}

\author{
Rutger Gyllenram ${ }^{1,2}$ (D) Niloofar Arzpeyma ${ }^{2} \cdot$ Wenjing Wei $^{1,2} \cdot$ Pär G. Jönsson ${ }^{1}$
}

Received: 15 January 2021 / Accepted: 15 April 2021 / Published online: 20 May 2021

(C) The Author(s) 2021

\begin{abstract}
The pressure on the steel industry to reduce its carbon footprint has led to discussions to replace coke as the main reductant for iron ore and turn to natural gas, bio-syngas or hydrogen. Such a major transition from the blast furnace-basic oxygen furnace route, to the direct reduction-electric arc furnace route, for steel production would drastically increase the demand for both suitable iron ore pellets and high-quality scrap. The value for an EAF plant to reduce the $\mathrm{SiO}_{2}$ content in DRI by 2 percentage points and the dirt content of scrap by 0.3 percentage points $\mathrm{Si}$ was estimated by using the optimization and calculation tool RAWMATMIX®. Three plant types were studied: (i) an integrated plant using internal scrap, (ii) a plant using equal amounts of scrap and DRI and (iii) a plant using a smaller fraction of DRI in relation to the scrap amount. Also, the slag volume for each plant type was studied. Finally, the cost for upgrading was estimated based on using mainly heuristic values. A conservative estimation of the benefit of decreasing the silica content in DRI from 4 to $2 \%$ is $20 \mathrm{USD} / \mathrm{t}$ DRI or $15 \mathrm{USD} / \mathrm{t}$ DR pellets and a conservative figure for the benefit of decreasing the dirt in scrap by 0.3 percentage points $\mathrm{Si}$ is $9 \mathrm{USD} / \mathrm{t}$ scrap. An estimate on the costs for the necessary ore beneficiation is $2.5 \mathrm{USD} / \mathrm{t}$ pellet concentrate and for a scrap upgrade, it is $1-2 \mathrm{USD} / \mathrm{t}$ scrap.
\end{abstract}

Keywords DRI · Ore beneficiation · Scrap upgrading $\cdot$ Slag volume

JEL Classification Q30 · Q31 · Q40 · Q54 · Q55

\section{Introduction}

This paper addresses the need for investments in ore beneficiation and scrap upgrading in the decades to come in order to meet demands on mitigating emissions of greenhouse gases as discussed at the AIST Scrap Supplements and Alternative Ironmaking 8, Orlando 2020 (Gyllenram et al. 2020). The theme of the conference was high-quality raw material supply for electric steel production, which is an increasingly important topic in view of the actual development in the steel industry.1.1 steel production, ore and scrap trade.

Rutger Gyllenram

rfgy@kth.se

1 Department of Materials Science and Engineering, Royal Institute of Technology, 10044 Stockholm, Sweden

2 Kobolde \& Partners AB, Ringvägen 100, SE-11860 Stockholm, Sweden

\section{Today's challenge and its future solutions}

Of the 40,000 Mt of $\mathrm{CO}_{2}$ emitted by human activities each year, the steel industry accounts for 7-9\% (World Steel Association 2018). Therefore, the international steel industry is under an immense pressure to lower its emissions of $\mathrm{CO}_{2}$. Regional goals to become carbon neutral the coming years, the EU in 2050 (EC 2019) and China in 2060 (Xi Jinping at UN General Assembly September 2020 imply that major changes must take place in the coming decades. A vast number of new technologies are being suggested, developed and evaluated to determine how improvements of all parts of the steel supply chain can be implemented (Cavaliere 2019). Common principles when making these improvements are as follows: an increased utilization of the reduction gas like top gas recycling, a reduction of the number of process steps like the HISarna smelting reduction process and replacing coal as a reductant with natural gas, hydrogen, biogenic syngas and/or biocarbon (Quader et al. 2016). In addition, carbon capture and storage, CCS, and carbon capture and utilization, $\mathrm{CCU}$, are two technologies developed to avoid $\mathrm{CO}_{2}$ generated 
in industrial processes to contribute to global warming, which are still in an early stage of deployment but may in the future become important tools in an abatement of $\mathrm{CO}_{2}$ emissions (Tanzer et al. 2020; Acatech - Deutsche Akademie der Technikwissenschaften 2018).

\section{BF-BOF route}

In 2019, the world production of crude steel was $1867.5 \mathrm{Mt}$ and the main route was the blast furnace-basic oxygen furnace route, BF-BOF, producing some $1343 \mathrm{Mt}$ representing $71.9 \%$ of the total steel production (World Steel Association 2020). The main ore burden in the $\mathrm{BF}$ is sinter made from sinter fines. Other common burden materials are lump ore and BF pellets.

\section{DR-EAF route}

Electric steel production using scrap, direct reduced iron, DRI and other metallic raw materials was $517 \mathrm{Mt}$ in 2019 representing $27.7 \%$ of the global steel production. The same year the production of DRI, used mainly in the direct reduction-electric arc furnace route, DR-EAF, was $107.6 \mathrm{Mt}$ (World Steel Association 2020). The gas-based fraction of DRI production, i.e. from Midrex or HYL/Energiron processes, is around $80 \%$ (Midrex technologies Inc 2018) and can therefore be estimated to $86 \mathrm{Mt}$. The production of DRI can be compared to the production of $\mathrm{BF}$ pig iron, which was almost 12 times as high or $1280.7 \mathrm{Mt}$ in 2019 (World Steel Association 2020). The gas-based DR-EAF route is today a well-established way to produce iron from iron ore, which results in lower $\mathrm{CO}_{2}$ emissions compared to the BF-BOF route. The DRI is either melted in an EAF plant adjacent to the DR plant or transported to other plants as either DRI or hot briquetted iron, HBI, for further processing. Since the reducing gas from natural gas contains $66 \%$ hydrogen, the $\mathrm{CO}_{2}$ emission is considerably lower compared to the use of coke or coal as a reductant. By using pure hydrogen or a biogenic synthetic reduction gas, syngas, the fossil $\mathrm{CO}_{2}$ emissions can be further reduced or even omitted.

\section{Raw materials}

The global production of iron ore products in 2019 including China was $2346 \mathrm{Mt}$ whereof $1845 \mathrm{Mt}$ consisted of sinter fines, lump ore and other iron ore products and the remaining 501 Mt consisted of BF and DR pellets. Figures excluding China are for the same year $2105 \mathrm{Mt}$ and $361 \mathrm{Mt}$, respectively (Löf and Löf 2020). The consumption of DR pellets necessary for gas-based DRI production can be estimated to $117 \mathrm{Mt}$, when assuming an $\mathrm{Fe}$ content of $67.8 \%$ in the DR pellets and $92.23 \%$ in the DRI. Since little gas-based DRI production takes place in China, it can be stated that the BF-pellet consumption outside China is $244 \mathrm{Mt}$ or slightly more than twice the DR-pellet production.

Whereas ore production can be increased with increasing demands, the scrap available for the steel industry is dependent on the consumption behaviour and can only to a limited degree be increased through better collection systems. However, it should be noted that the available scrap is fixed and if the demand increases too much, only ores can contribute to meet an increased demand.

\section{Raw material quality}

From an ore quality perspective, the BF-BOF route is much less sensitive to the percentage of gangue elements such as $\mathrm{SiO}_{2}, \mathrm{Al}_{2} \mathrm{O}_{3}$ and $\mathrm{TiO}_{2}$ in the feed compared to the requirements in the DR-EAF route. Most of the gangue elements are transferred into the BF slag with a volume between 150 and $300 \mathrm{~kg} / \mathrm{t}$, a basicity around 1 and an iron content typically less than $1 \%$. The subsequent BOF receives a liquid hot metal with an Si content which normally is between 0.2 and $0.7 \%$. Decreasing the silica input to the BF decreases the slag volume, the fuel rate, and improves the productivity. The silicon content in the hot metal is also decreased although the relationship is complex. Experiences from development at the BF plant in Luleå indicate that a practical limit for a BF pellet is a minimum $\mathrm{SiO}_{2}$ content of approximately $2 \%$, depending on the performance in the furnace (Wikström 2020 private communication). Hooey et al. (2014) report that migration from sinter to pellets in the BF has a large potential to save energy in the BF. This implies that decreasing the silica content in BF pellets may have a lower priority. The DR process on the other hand is a solid-state reduction process and the gangue in the DR pellet stays in the DRI and enters the EAF, so high levels of gangue result in high slag amounts in the steelmaking process (Turcotte et al. 1985).

The silicon in the hot metal and silica and other gangue elements in the DRI affect the amount of slag formers that has to be added to the BOF or the EAF in order to reach $\mathrm{MgO}$ saturation of the slag, and the basicity is typically around 2 or more. The $\mathrm{MgO}$ saturation is a function of slag temperature and composition including all components such as $\mathrm{FeO}$, $\mathrm{CaO}, \mathrm{SiO}_{2}, \mathrm{P}_{2} \mathrm{O}_{5}, \mathrm{Al}_{2} \mathrm{O}_{3}, \mathrm{TiO}_{2}$ and $\mathrm{VO}_{2}$. The EAF slag practice aims at reaching a slightly oversaturated slag. This requires certain amounts of lime (ordinary and dolomitic) to be added during the smelting process, the higher the DRI gangue content, the higher the amounts of lime, which affects the process economy of the DR-EAF route.

The produced DRI may be used as hot DRI, which is used at integrated DR-EAF plants, cold DRI, used at both integrated DR-EAF plants and plant using a large amount of scrap and finally hot briquetted iron, HBI, which is a standard product used at scrap-based plants. The use of hot DRI, applied at some integrated DR-EAF plants, offers substantial energy 
savings. Over the years, a number of research work have been done to describe the relation between slag composition and $\mathrm{MgO}$ content at saturation like Suito et al. (1981) and Selin (1987, 1991). Examples of recent work are Kirschen (2021) and finally Song et al. (2020) studying refractory wear. Economic assessments of DRI quality and DRI use have been made by Gyllenram et al. (2015a) and Gyllenram et al. (2015b).

The reducibility of the DR pellets depends on the particle ore porosity, particle size and chemical composition of the phases present in the ore. A low reducibility results in either a low production rate in the DR furnace or a low metallization degree of the DRI (Chapa and Duarte 2001). Upgrading an iron ore concentrate to reach a lower gangue content of compounds such as silicates and alumina may include further comminution, a combination of magnetic separation, gravimetric separation in spirals and flotation. These methods must, according to LKAB DR-pellet specialists, be customized based on the requirements for each deposit (Magnus Tottie 2020 private communication).

As an example, Table 1 presents the development of LKAB DRI pellets from 1978 to 2017 showing a reduction of the $\mathrm{SiO}_{2}$ content from 1.43 to $0.8 \%$ over 40 years (Rutschman and Tottie 2018).

Another example has been presented by RioTinto, where the silica content in DR pellets was decreased from 4.5 to under $1 \%$ through the implementation of silica flotation (Chaigneau 2015). However, the benefits of obtaining a higher iron content in the ore product must be weighed against the iron losses due to the separated gangue, the tailing grade and a property varying with the ore mineralogy. The tailing grade may vary from low levels below $10 \%$ under favourable conditions to high levels well over 20\% (Xiong et al. 2015).

The importance of scrap quality from the perspective of the tramp element contents in electric steelmaking is well known and documented, since they affect the steel quality and show in the steel chemical analysis (Boom and Steffen 2001). However, silica from foreign material such as dirt and other steriles appears mainly in the slag and is therefore often neglected. This is probably due to that the slag in the EAF process, normally around $70 \mathrm{~kg} / \mathrm{t}$ for $100 \%$ scrap-based steelmaking, is not homogenous and as a consequence very

Table 1 An LKAB iron ore gangue content reduction from 1978 to 2017

\begin{tabular}{lllll}
\hline Product & Year & $\mathrm{SiO}_{2}$ & $\mathrm{Al}_{2} \mathrm{O}_{3}$ & $\mathrm{TiO}_{2}$ \\
\hline MPR & 1978 & 1.43 & 0.53 & 0.32 \\
MPRD & 1980 & 1.2 & 0.4 & 0.25 \\
MPRD & 1995 & 0.95 & 0.24 & 0.16 \\
KPRS & 2017 & 0.8 & 0.16 & 0.18 \\
\hline
\end{tabular}

difficult to study. Treating scrap indoors and having a hard surface on the scrap yard are methods that can be applied to avoid dirt to stick to the scrap. Furthermore, scrap upgrading can be done by an extra shredding step or heavy metal scrap, HMS, cleaning systems, which improve the scrap quality by reducing the waste/dirt content and non-ferrous metal contents (Guschall 2020 private communication). The potential of scrap upgrading depends on the initial scrap quality as well as on the local conditions with respect to the scrap supply chain and EAF plant facilities.

The capability to cope with large slag amounts depends on the EAF design, and slag amount around $150 \mathrm{~kg} / \mathrm{t}$ steel is not uncommon in integrated DR-EAF plants especially when producing low carbon steels where the $\mathrm{FeO}$ content in slag is high (Turcotte et al. 1985; Roger Selin 2021 private communication). Such high slag amounts result in iron losses in the slag, about $4 \%$, lower productivity and higher lime and energy consumptions, all affecting steelmaking economy. By using DRI from higher grade iron ore feed, slag/steel ratios in the order of $100-120 \mathrm{~kg} / \mathrm{t}$ are possible for high DRI percentage in the charge (over 80\%) with corresponding improvements on the abovementioned factors and the resulting economy (Roger Selin, 2021 private communication). In this paper, a slag volume of $100 \mathrm{~kg} / \mathrm{t}$ is used as a reference and desirable upper limit.

\section{Changing market}

Abating $\mathrm{CO}_{2}$ emissions from the steel industry may in the future involve a number of different processes deployed, depending on available raw materials, energy and other factors like for example existing installations and engineering traditions. According to the International Energy Agency, IEA International Energy Agancy (2020), two main production routes constitute basic alternatives:

A. An improved BF-BOF route with $\mathrm{CCS} / \mathrm{CCU}$ is suggested by the IEA to be the main route to iron and steel from ore in the future. The main incentive for this route is that it may use a large base of newly erected BF-BOF plants with the same ore feed as today as a basis for new technical solutions.

B. An increased production in the DR-EAF route partly replacing ageing BF-BOF plants. The main incentive for this alternative is the high technology readiness level, TRL, of DR processes. This development will demand an increased supply of DR pellets with a low gangue content and an increased demand of high-quality scrap. To begin with, this route will probably depend on natural gas as reductant until alternatives are available and a stepwise transition to fossil free production can be implemented. In order to further improve solutions, CCS/ 
CCU may be used when other reductants than hydrogen are used.

Apart from a possible limited capacity to erect new beneficiation and pelletizing plants, at least three conceivable development scenarios may limit the transition in alternative $B$ :

i. Smelting reduction technology based on the BF-BOF route is developed to cope with the demands on $\mathrm{CO}_{2}$ emissions in a way that it stays competitive with the DR-EAF route in a long-term perspective.

ii. Availability of global iron ore resources that allow for upgrading to DR quality at a cost that is competitive limits the possible transition.

iii. Market conditions limit the DR premium level and premium stability in a way that slows down investment in DR quality pellet production and as a consequence the DRI production capacity.

In a long-term perspective, the first and second scenarios are plausible and may shape the production structure approaching 2050. In the short term, however, an uncertainty about the future demand for DRI and lack of stability in the DR premium may be the biggest obstacles to increased investments in DR-grade production.

Assuming that the steel production outside China remains stable at the 2019 level and actions are taken to reach the climate goals, both alternatives A and B must be deployed in a remarkable pace. To reach carbon neutrality, alternative $\mathrm{B}$ has a higher TRL level compared to alternative A and therefore probably a lower technical and financial risk.

If, in the next 30 years, $25 \%$ of today's world pig iron production would migrate from the BF-BOF route to the DR-EAF route, it would mean a need for replacing $320 \mathrm{Mt}$ pig iron with approximately $330 \mathrm{Mt}$ DRI. This, in turn, would require an increased production of some additional $448 \mathrm{Mt}$ of DR pellets. A more conservative transition of 5\% replacing 64 Mt pig iron would require an additional amount of $90 \mathrm{Mt}$ of DR pellets. For comparison, the assumed capacity increase from 2019 until 2025 is estimated to around $20 \mathrm{Mt}$ (Barrington 2020).

For most of the existing supply chains, such investments must be made by the raw material suppliers while the benefits are experienced by the raw material users, as outlined in Fig. 1. Both an ore beneficiation and a scrap upgrading result in an iron loss in the processing. Iron will leave the system with traces of premium ore or with a poorer ore fraction in the ore beneficiation residue or as shrapnel in a dirt residue in the scrap upgrading step. Other major costs for decreasing the silica content are capital costs for plants, manpower, maintenance, electricity and flotation reagent for ore beneficiation, and electricity for scrap upgrading.
A low silica content in the raw materials on the other hand benefits the DR-EAF steps. The DR plant benefits from a higher productivity and decreased gas consumption, when less material needs to be heated and treated. However, the main benefit is in the EAF step where lower amounts of slag formers result in a lower slag amount and therefore a lower $\mathrm{Fe}$ loss. Other major benefits are a lower consumption of energy and a higher productivity.

In order to share the benefit of higher raw material qualities, a stable quality premium must be agreed on and maintained. The pricing mechanism that takes into account the performance of the raw material in the process is therefore of the greatest importance in order to create incentives for suppliers to invest in improving raw material qualities, scrap or DR pellets alike. Today's pricing mechanism for iron ore has one premium for pelletization and another premium for a DR grade.

The migration to DR-EAF takes place on a diverse market. Three different DR-EAF plant types can be identified:

1) The integrated DR-EAF plant using mainly a DRI burden and a minor part of internal scrap,

2) The one-basket plant, charging the furnace with one basket of scrap, and then charging DRI or HBI through the furnace roof and

3) The scrap-based plant using DRI or HBI as a clean scrap to decrease the levels of tramp elements in the charged material.

A replacement of the pig iron production with a DRI production in integrated DR-EAF plants such as in the production case 1 would require an amount of scrap of the same magnitude as in the BF-BOF route, while new plants such as in cases 2 and 3, replacing BF-BOF plants, would drastically strain the scrap market. On the other hand, an existing scrap-based EAF plant adapting the case 2 or case 3 use of DRI would release scrap to the market.

Finally, plants operating according to cases 2 or 3 would depend on merchant DRI/HBI suppliers. These can be either independent or captive i.e. owned by the steelmaker or a DRpellet producer, all supplying to several plants. A case 1 plant may also act as a merchant DRI/HBI supplier, selling excess DRI/HBI on the open market.

In a case where alternative $B$ is realized and a vast number of BF-BOF plants are closed and replaced by electric steelmaking plants, investments must be made to secure the sourcing of DR pellets and high-quality scrap. The aim of this paper is to motivate these investments by showing the importance of the raw material quality to reach a successful migration from the BF-BOF route to the DR-EAF route. Furthermore, the study aims at providing a basis to calculate the potential improvement in revenue by investing in ore beneficiation and scrap upgrading facilities. 


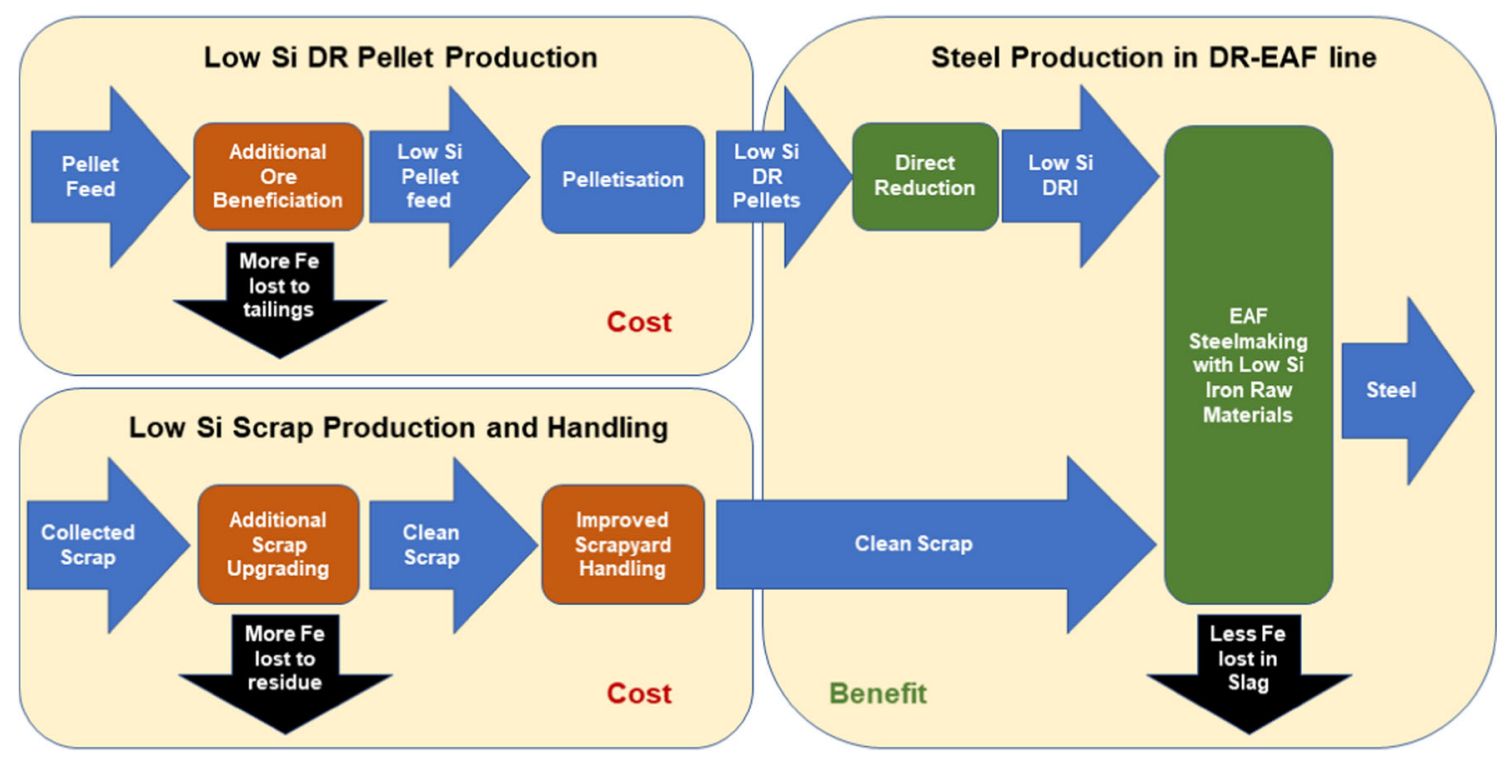

Fig. 1 Costs and benefits of decreasing the silica content in iron bearing raw materials in the DR-EAF supply chain. The black arrows indicate the changes in loss of iron to tailings, scrap residue or slag. Other benefits in

the steel production box are increased productivity, decreased energy and slag former use. The figure does not describe aspects related to the plant ownership or plant location

Both scrap and DRI qualities are taken into account, since the amounts of gangue in DRI and foreign material in scrap both influence the performance of the EAF in a negative way and improving the quality in scrap may be necessary for some plants in order to control the slag amount when increasing the use of DRI/HBI.

\section{Methods}

The cost benefit analysis that is the core of this study is performed in the following steps:

Step 1: A parameter study is performed for three commercial DR-pellet types with different chemical compositions and scrap containing three different levels of "dirt". The study is performed for three production cases, one for each plant type named in the "Changing market" section.

Step 2: For the sake of simplicity, the $\mathrm{Si}_{\text {tot }} / \mathrm{SiO}_{2}$ content is chosen as the quality parameter in the calculations. The $\mathrm{Si}_{\text {tot }}$ is used for scrap including both the metallic and oxidic Si contents. The postulated ore beneficiation and scrap upgrading result in a decrease in the $\mathrm{SiO}_{2}$ content in DRI by 2 percentage points, $\mathrm{pp}$, and a decrease in the $\mathrm{Si}_{\text {tot }}$ content in scrap by $0.3 \mathrm{pp}$.

Step 3: A linear relationship is assumed within the space defined by the silica content of the raw materials and the beneficiation and upgrading may start at an arbitrary point within this space.

Step 4: The impact on cost, slag formation, resource consumption, iron loss and emissions from the postulated improvements of the DRI and scrap qualities is calculated from the data in the parameter study, by assuming a linear relationship between the mentioned quantities and $\mathrm{Si}_{\text {tot }} / \mathrm{SiO}_{2}$ content in scrap/DRI.

Step 5: Slag amounts from the parameter study are linearized as a function of the silica in DRI and scrap and used in visualizing the relationship between raw material silica and slag volumes.

Step 6: Costs for ore beneficiation and scrap upgrading are estimated based on synthetic data for a pellet concentrate and for scrap.

Step 7: Finally, costs and benefits are compared in order to establish the incentive for investments made by the raw material suppliers.

This following section describes the models used in the calculations and the calculation procedure.

\section{Model description}

The optimization and calculation tool RAWMATMIX® is applied to perform mass and energy balances for the DREAF route. Standard raw material data in the system, used in the study, are given by Arzpeyma and Gyllenram (2021). The DR process model together with plant data is described by Gyllenram and Arzpeyma (2021) and the EAF model is described and validated by Arzpeyma et al. (2020). Calculation of $\mathrm{MgO}$ saturation is based on the work of Selin $(1987,1991)$ including a copyrighted digitalization algorithm. Total emissions of $\mathrm{CO}_{2}$ are calculated for the final product by taking all major upstream sources into account. The emissions are 
reported separately for production of DRI and scrap, other emission sources like energy and summed to a total figure. Emissions for ore beneficiation and scrap upgrading are not included.

\section{DR}

The DRI composition is calculated using a mass balance, based on the iron ore pellet chemical composition. The calculation is done to meet the goals for metallization and carbon, which are set as input values. The model estimates the production cost of DRI based on consumption figures for raw materials, energy, raw material and energy prices as well as the calculated operational and capital costs for the plant. The production cost is set as the DRI price in the EAF process and the calculated $\mathrm{CO}_{2}$ emission is set as the DRI upstream carbon footprint value.

\section{EAF}

The EAF process model is based on a mass and energy balance, where the main charged materials are DRI/HBI and scrap. A cost-optimized raw material mix is calculated based on a specification of the target product, available raw materials and charging constraints; furthermore, an optimal addition of slag formers is calculated based on the need for a slightly $\mathrm{MgO}-$ oversaturated slag. Also, the electricity consumption is calculated in order to reach the selected tap temperature taking into account other energy sources added as fixed inputs like oxy fuel burners and oxygen. The required pulverized coal injection is calculated based on a set oxygen input and demand for an additional reduction of iron oxide. A tap-to-tap time is calculated based on average power on for the furnace, electricity consumption and a given power off time. The model finally estimates the production cost of liquid steel, based on the calculated consumption figures for raw materials and energy, raw material and energy prices as well as the calculated plant fixed operational costs, fixed OPEX, and capital costs, CAPEX.

\section{Iron ore beneficiation and scrap upgrading}

The cost in USD for iron ore beneficiation from a BF-pellet concentrate to a low silica DR-pellet concentrate and scrap upgrading from a low-grade (dirty) scrap to clean scrap is modelled as shown in Eq. 1:

$$
\text { Cost }=\mathrm{PC}+\mathrm{IL} \times \mathrm{IP} /(1000-\mathrm{IL})+\mathrm{RC}
$$

where $\mathrm{PC}$ is the process cost (USD/t processed concentration or scrap) which is dependent on ore and scrap properties, IL is the iron loss $(\mathrm{kg} / \mathrm{t}$ non processed concentration or scrap) in tailings or scrap cleaning residue, IP is the iron price (USD/ t) and $\mathrm{RC}$ is the cost for taking care of residues (USD/t processed concentration or scrap) which is dependent on local conditions. In the calculations, $\mathrm{PC}+\mathrm{RC}$ are set to heuristic values given by actors on the market.

\section{Calculation procedure and basic data}

Three iron ore pellets existing in the market with different contents of silica are studied. For DRI calculations, the metallization and carbon contents are set to $94 \%$ and $2 \%$, respectively. The chemical compositions of the iron ore pellets and their corresponding DRI products are shown in Table 2. DRI products are defined as DRI L, DRI M and DRI H, corresponding to the low, medium and high $\mathrm{SiO}_{2}$ contents.

The scrap analysis used is typical for the scrap category "old thick", in Europe referred to as E3 and in the USA as HMS 1, which contains three different contents of Si present in both metallic and silica forms, as shown in Table 3. The scrap types are defined as scrap L, scrap M and scrap H, corresponding to the low, medium and high $\mathrm{SiO}_{2}$ contents. Note that nothing is stated about what is a normal amount of

Table 2 The chemical compositions of the iron ore pellets and their corresponding DRI products

\begin{tabular}{|c|c|c|c|c|c|c|}
\hline \multirow[b]{2}{*}{ Properties } & \multicolumn{6}{|c|}{ Pellet type and resulting calculated DRI } \\
\hline & \multicolumn{2}{|c|}{ Low $\mathrm{SiO}_{2}$} & \multicolumn{2}{|c|}{ Medium $\mathrm{SiO}_{2}$} & \multicolumn{2}{|c|}{ High $\mathrm{SiO}_{2}$} \\
\hline $\mathrm{m}_{\text {Pellet }} / \mathrm{m}_{\mathrm{DRI}}$ & 1.361 & & 1.360 & & 1.342 & \\
\hline Material & Pellet & DRI L & Pellet & DRI M & Pellet & DRI H \\
\hline $\mathrm{Fe}_{\text {tot }}$ & 68.1 & 92.66 & 67.8 & 92.23 & 67.4 & 90.43 \\
\hline Acid gangue & 1.53 & 2.08 & 2.08 & 2.83 & 3.61 & 4.87 \\
\hline $\mathrm{Fe}$ & 0 & 87.1 & 0 & 86.7 & 0 & 85.01 \\
\hline $\mathrm{C}$ & 0 & 2 & 0 & 2 & 0 & 2 \\
\hline $\mathrm{FeO}$ & 0 & 7.15 & 0 & 7.12 & 0 & 6.98 \\
\hline $\mathrm{SiO}_{2}$ & 1 & 1.36 & 1.6 & 2.18 & 3.4 & 4.59 \\
\hline $\mathrm{CaO}$ & 0.57 & 0.88 & 0.54 & 0.73 & 0.53 & 0.72 \\
\hline $\mathrm{Fe}_{2} \mathrm{O}_{3}$ & 95.58 & 0 & 95.63 & 0 & 94.27 & 0 \\
\hline $\mathrm{Fe}_{3} \mathrm{O}_{4}$ & 1.61 & 0 & 1.29 & 0 & 1.28 & 0 \\
\hline $\mathrm{MgO}$ & 0.28 & 0.38 & 0.2 & 0.27 & 0.17 & 0.23 \\
\hline $\mathrm{MnO}$ & 0.15 & 0.21 & 0.13 & 0.18 & 0 & 0 \\
\hline $\mathrm{P}_{2} \mathrm{O}_{5}$ & 0.06 & 0.08 & 0.1 & 0.14 & 0.02 & 0.03 \\
\hline $\mathrm{Al}_{2} \mathrm{O}_{3}$ & 0.48 & 0.65 & 0.45 & 0.61 & 0.18 & 0.24 \\
\hline $\mathrm{TiO}_{2}$ & 0.05 & 0.07 & 0.03 & 0.04 & 0.03 & 0.04 \\
\hline $\mathrm{Na}_{2} \mathrm{O}$ & 0.004 & 0.01 & 0.01 & 0.01 & 0.08 & 0.11 \\
\hline $\mathrm{K}_{2} \mathrm{O}$ & 0.005 & 0.01 & 0.01 & 0.01 & 0.04 & 0.05 \\
\hline $\mathrm{VO}_{2}$ & 0.05 & 0.07 & 0 & 0 & 0 & 0 \\
\hline $\mathrm{CaCO}_{3}$ & 0.14 & 0 & 0 & 0 & 0 & 0 \\
\hline Others* & 0.031 & 0.036 & 0.009 & 0.011 & 0.001 & 0.001 \\
\hline
\end{tabular}

*The other elements include $\mathrm{Mo}, \mathrm{Cu}, \mathrm{Ni}, \mathrm{Cr}_{2} \mathrm{O}_{3}, \mathrm{NiO}, \mathrm{CuO}$ and $\mathrm{SnO}_{2}$ 
Table 3 The chemical compositions of the charged scrap types. The $\mathrm{SiO}_{2}$ content represents a dirt fraction

\begin{tabular}{llll}
\hline & \multicolumn{2}{l}{ Scrap type } & \\
\cline { 2 - 4 } Element & $\begin{array}{l}\text { Low } \mathrm{SiO}_{2} \\
(\text { scrap L) }\end{array}$ & $\begin{array}{l}\text { Medium } \mathrm{SiO}_{2} \\
\text { (scrap M) }\end{array}$ & $\begin{array}{l}\text { High } \mathrm{SiO}_{2} \\
\text { (scrap H) }\end{array}$ \\
\hline $\mathrm{Fe}$ & 98.013 & 97.373 & 96.733 \\
$\mathrm{C}$ & 0.4 & 0.4 & 0.4 \\
$\mathrm{Si}$ & 0.3 & 0.3 & 0.3 \\
$\mathrm{P}$ & 0.02 & 0.02 & 0.02 \\
$\mathrm{~S}$ & 0.025 & 0.025 & 0.025 \\
$\mathrm{Mn}_{\mathrm{SiO}}$ & 0.8 & 0.8 & 0.8 \\
$\mathrm{Other}_{\mathrm{Si}}\left(\mathrm{Si}+\mathrm{Si}\right.$ in $\left.\mathrm{SiO}_{2}\right)$ & 0.3 & 0.64 & 1.28 \\
\hline
\end{tabular}

silica in this scrap category. It is entirely dependent on local conditions and management.

Main values for the plant operation are shown in Table 4. The CAPEX + fixed OPEX and consumption figures for both the shaft furnace and the electric arc furnace as well as the consumption figures for the DR furnace are estimated from data reported from various undisclosed market actors.

For seaborne pellets, the free onboard, FOB, dry pellet price in USD/t is calculated from a market price on the iron in ore products of a certain category and the iron content of the specific ore pellets. Freight, including costs for loading and unloading, moisture content is then added to get the price at the production site.

The price for iron in ore products and scrap does not change with the silica content. Instead, the difference in production cost of steel using the different products indicates what price premium a more refined ore product or scrap should have. Prices for input materials, electricity, electrodes, slag/dust disposal costs, other additional costs and parameters used to estimate DRI prices are summarized in Table 5.

In this study, the prices for natural gas and electricity are representative for a high-cost location, whereas the iron materials are based on current price averages.

In all EAF calculations, the desired values for the slag parameters, $\mathrm{FeO}^{*}, \mathrm{CaO}_{20}, \lambda_{\mathrm{P}}$ and $\lambda_{\mathrm{V}}$, are set to $20 \%, 38 \%, 1$ and 1 , respectively and the oversaturation factor, $\lambda_{\mathrm{MgO}}$, is set to 1.1 (Arzpeyma et al. 2020). The slag formers include burnt lime and dolomite. Besides, it is assumed that in each charge, an amount of $0.5 \mathrm{~kg} / \mathrm{t}$ steel refractory is dissolved into the slag. The steel produced is raw steel for a standard construction steel with $0.2 \% \mathrm{C}$ and no requirements on tramp elements or alloys that affect the optimization.

Three cases for production of $100 \mathrm{t}$ steel are defined using DRI and 20, 50 and $80 \mathrm{t}$ scrap. These cases correspond to cases 1,2 and 3, respectively in the "Changing market" section.

In total, 27 calculations were made for the DR-EAF route, taken into account three variables as presented in Table 6 . The tap weight and the amounts of the charged scrap were set as constraints in charge optimizations. This means that the amount of DRI is estimated by the system to result in a production of $100 \mathrm{t}$ steel.

To facilitate comparisons, it is assumed that the DRI is transported and charged into the EAF as a cold DRI for all production cases: Furthermore, benefits of avoiding a second basket of scrap are not taken into account in the calculations. The reasoning is restricted to $\mathrm{SiO}_{2}$ for DRI and $\mathrm{Si}_{\text {tot }}$ for scrap in this general study. Thus, the study does not intend to compare the usefulness of DRI and scrap as suitable raw materials for the EAF. The results from the calculations are presented in Tables 7, 8 and 9.

A linear performance of the slag amount as a function of the silica contents in DRI and scrap is assumed, according to Eq. 2, to calculate iso-slag lines in Figs. 6, 8 and 10.
Table 4 Main plant production factors

\begin{tabular}{llll}
\hline Production factor & Unit & Amount & Comment \\
\hline $\begin{array}{llll}\text { DR furnace CAPEX + fixed OPEX } & \text { MUSD/y } & 34.4 & \\
\text { DR annual production } & \text { Mt } & 0.832 & 100 \text { t DRI/h, furnace } \\
\text { availability of } 95 \%\end{array}$ \\
DR natural gas consumption & GJ/t DRI & 10 & \\
DR electricity & $\mathrm{kWh} / \mathrm{t}$ DRI & 100 & \\
DRI metallization degree & $\%$ & 94.0 & \\
DRI carbon content & $\%$ & 2 & \\
EAF CAPEX + fixed OPEX & $\mathrm{MUSD} / \mathrm{y}$ & 31.1 & \\
EAF tap volume & $\mathrm{t}$ & 100 & \\
EAF tap temperature & ${ }^{\circ} \mathrm{C}$ & 1650 & 60 \\
EAF average power on & $\mathrm{MW}$ & & \\
\hline
\end{tabular}


Table 5 The main cost factors and energy/material prices

\begin{tabular}{lllll}
\hline Raw Material/ Service & Unit & $\begin{array}{l}\text { Cost/price } \\
\text { (USD/unit) }\end{array}$ & $\begin{array}{l}\text { Upstream } \mathrm{CO}_{2} \\
(\mathrm{~kg} / \mathrm{unit})\end{array}$ & Comment \\
\hline Pellets FOB & $\mathrm{t}$ Fe in ore & 80 & - & \\
Pellets freight & $\mathrm{t}$ & 22 & - & \\
Destination port fines & $\%$ & 3 & - & Loss as fines during unloading \\
Moisture & $\%$ & 2 & - & \\
Low Si pellets & $\mathrm{t}$ & 79.3 & 137 & Dry, see Table 2 \\
Medium Si pellets & $\mathrm{t}$ & 79.1 & 137 & Dry, see Table 2 \\
High Si pellets & $\mathrm{t}$ & 78.7 & 137 & Dry, see Table 2 \\
Scrap & $\mathrm{t}$ & 220 & 7 & See Table 3 \\
Lime & $\mathrm{t}$ & 120 & 950 & $100 \% \mathrm{CaO}, 1 \%$ moisture \\
Dolomite & $\mathrm{t}$ & 150 & 1100 & $70 \% \mathrm{CaO}, 30 \% \mathrm{MgO}, 1 \%$ moisture \\
Magnesite bricks & $\mathrm{t}$ & 500 & 1090 & $100 \% \mathrm{MgO}$ \\
Natural gas & $\mathrm{Nm}$ & 0.6 & 0.665 & $0.038 \mathrm{GJ} / \mathrm{Nm}{ }^{3}$ \\
LPG & $\mathrm{GJ}$ & 0.14 & 6.2 & $0.1 \mathrm{GJ} / \mathrm{Nm}{ }^{3}$ \\
Electricity & $\mathrm{kWh}$ & 0.1 & 0.49 & Produced from natural gas \\
Pulverized coal & $\mathrm{t}$ & 1170 & 790 & \\
Oxygen & $\mathrm{Nm}{ }^{3}$ & 0.12 & 0.235 & \\
Electrode & $\mathrm{t}$ & 4660 & 650 & \\
EAF slag disposal & $\mathrm{t}$ slag & 30 & - & - \\
EAF dust disposal & $\mathrm{t}$ dust & 30 & - & \\
EAF additional & $\mathrm{t}$ metal & 10 & & \\
\hline
\end{tabular}

Slag amount (SA) : $S A=a \times \% \mathrm{SiO}_{2} D R I+b$

$$
\times \% S i_{\text {tot }} \text { SCRAP }+c
$$

The parameters $a, b$ and $c$ are listed in Table 10 .

The upgrading cases considered in the benefit scenario studies are (i) a reduction of the $\mathrm{SiO}_{2}$ content in DRI from 4 to $2 \%$ and (ii) a reduction of the silica content in scrap from 0.8 to $0.5 \% \mathrm{Si}_{\text {tot }}$. The calculated benefits are presented in Table 11.

The potential iron loss in ore beneficiation of three hypothetical ores with a rich fraction consisting of haematite containing $1 \% \mathrm{Si}$ and $67 \% \mathrm{Fe}$ and having a fraction consisting of $70 \% \mathrm{SiO}_{2}$ and $10 \%, 15 \%$ and $20 \% \mathrm{Fe}$. In this calculation, the poor fraction is discarded and the iron loss is presented per ton of DR-pellet feed. A rough estimate for ore beneficiation discussed with DR specialists at LKAB is $2 \mathrm{USD} / \mathrm{t}$ pellet feed

Table 6 The charged scrap amounts and the $\mathrm{SiO}_{2}$ contents in DRI and $\mathrm{Si}_{\text {tot }}$ contents in scrap

\begin{tabular}{lll}
\hline $\begin{array}{l}\text { Scrap amounts } \\
\text { (t) in cases 1, 2, 3 }\end{array}$ & $\begin{array}{l}\mathrm{SiO}_{2} \text { in DRI (\%) } \\
\text { for DRI L, DRI M, } \\
\text { DRI H }\end{array}$ & $\begin{array}{l}\mathrm{Si}_{\text {tot in scrap types (\%) }} \\
\text { for scrap L, scrap M, } \\
\text { scrap H }\end{array}$ \\
\hline $20,50,80$ & $1.36,2.18,4.59$ & $0.3,0.6,0.9$ \\
\hline
\end{tabular}

plus the cost for iron losses (Gyllenram et al. 2020). The results are presented in Table 12.

The potential iron loss during the scrap upgrading process in the form of shrapnel and dust is assumed to be in the range of $0.1-0.5 \%$, which is lost with the residue from the process. A rule-of-thumb figure discussed with Sicon $\mathrm{GmbH}$ for the scrap upgrading cost is $1 \mathrm{USD} / \mathrm{t}$ scrap plus the cost for iron losses (Gyllenram et al. 2020).

\section{Results and discussions}

\section{Effect of decreasing $\mathrm{SiO}_{2}$ in DRI and $\mathrm{Si}_{\text {tot }}$ in scrap on EAF steel production}

In the "Effect of decreasing $\mathrm{SiO}_{2}$ in DRI and $\mathrm{Si}_{\text {tot }}$ in scrap on EAF steel production" section and the "Benefit analysis of ore beneficiation and scrap upgrade" section, it is shown how a decrease in the $\mathrm{SiO}_{2}$ content in DRI by 2 pp and a decrease in $\mathrm{Si}_{\text {tot }}$ in scrap by $0.3 \mathrm{pp}$ affect important production factors and thus affecting the steel production cost.

In Fig. 2, the reduction of the tap-to-tap time, slag amount and electricity consumption as a result of a decrease in $\mathrm{SiO}_{2}$ content in DRI by $2 \mathrm{pp}$ and a decrease in $\mathrm{Si}_{\text {tot }}$ in scrap by $0.3 \mathrm{pp}$ is presented for the three cases. A higher silica content in the burden results in a higher slag volume. This, in turn, 
Table 7 Production data for production case 1. Medium values for scrap are left out since the system shows a linear performance

Data

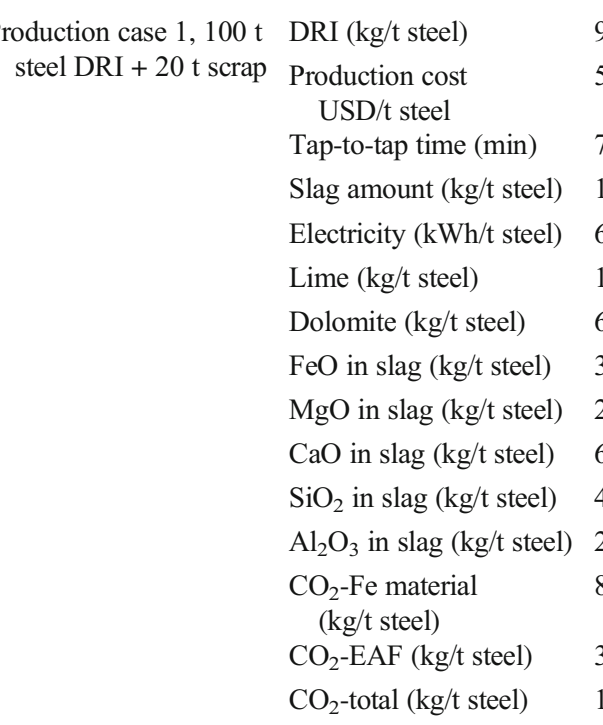

DRI H + DRI H + scrap L DRI M + scrap H DRI M + scrap L DRI L + scrap H DRI L + scrap $\mathrm{H}$

\begin{tabular}{llllll}
936 & 932 & 906 & 901 & 897 & 893 \\
503 & 499 & 475 & 472 & 467 & 464 \\
77 & 76 & 70 & 69 & 68 & 67 \\
179 & 169 & 110 & 101 & 86 & 77 \\
619 & 609 & 551 & 542 & 530 & 522 \\
13 & 12 & 12 & 12 & 12 & 12 \\
69 & 64 & 33 & 28 & 18 & 14 \\
35 & 33 & 22 & 20 & 17 & 15 \\
21 & 20 & 11 & 10 & 8 & 7 \\
67 & 64 & 41 & 38 & 33 & 29 \\
47 & 44 & 24 & 21 & 16 & 14 \\
2 & 2 & 6 & 6 & 6 & 6 \\
880 & 876 & 854 & 850 & 846 & 842 \\
398 & 387 & 325 & 316 & 299 & 290 \\
1278 & 1263 & 1178 & 1165 & 1145 & 1132 \\
\hline
\end{tabular}

needs more energy to melt the slag which increases the tap-totap time. For the integrated DR-EAF mill in production case 1, the more refined DRI product reduces the slag amount by 57 $\mathrm{kg} / \mathrm{t}$. This, in turn, reduces the electricity consumption by 54 $\mathrm{kWh} / \mathrm{t}$ and the tap-to-tap time by $5.4 \mathrm{~min}$. With an additional impact from scrap upgrading, the tap-to-tap time is decreased by almost 6 min. It can be seen that $\mathrm{SiO}_{2}$ reduction in DRI/ scrap in production case 1 results in a higher total reduction in slag volume and electricity consumption compared to production cases 2 and 3.

In order to obtain an $\mathrm{MgO}$ saturated slag, which is necessary to avoid an excess refractory, wear, lime and dolomite are added as slag formers. The model assumes that the FeO content in the slag is dependent on the carbon content of the steel produced and it is set to $20 \%$ in the liquid fraction of the slag in the calculations. In Fig. 3, the reduction of the consumption

Table 8 Production data for production case 2. Medium values for scrap are left out since the system shows a linear performance

\begin{tabular}{|c|c|c|c|c|c|c|c|}
\hline & Data & DRI H + scrap H & DRI H + scrap L & DRI M + scrap H & $\begin{array}{l}\text { DRI M + } \\
\text { scrap L }\end{array}$ & $\begin{array}{l}\text { DRI L + } \\
\text { scrap H }\end{array}$ & $\begin{array}{l}\text { DRI L + } \\
\text { scrap L }\end{array}$ \\
\hline \multirow{15}{*}{$\begin{array}{r}\text { Production case } 2,100 \mathrm{t} \\
\text { steel DRI }+50 \mathrm{t} \text { scrap }\end{array}$} & DRI (kg/t steel) & 608 & 597 & 589 & 577 & 583 & 572 \\
\hline & Production cost USD/t steel & 450 & 439 & 433 & 424 & 428 & 419 \\
\hline & Tap-to-tap time (min) & 71 & 68 & 66 & 64 & 65 & 63 \\
\hline & Slag amount (kg/t steel) & 148 & 124 & 104 & 81 & 89 & 66 \\
\hline & Electricity (kWh/t steel) & 556 & 531 & 514 & 494 & 501 & 481 \\
\hline & Lime $(\mathrm{kg} / \mathrm{t}$ steel $)$ & 15 & 13 & 14 & 12 & 14 & 12 \\
\hline & Dolomite (kg/t steel) & 53 & 42 & 30 & 20 & 21 & 12 \\
\hline & $\mathrm{FeO}$ in slag $(\mathrm{kg} / \mathrm{t}$ steel $)$ & 29 & 25 & 21 & 16 & 18 & 13 \\
\hline & $\mathrm{MgO}$ in slag (kg/t steel) & 16 & 13 & 10 & 7 & 8 & 6 \\
\hline & $\mathrm{CaO}$ in slag $(\mathrm{kg} / \mathrm{t}$ steel $)$ & 56 & 47 & 39 & 30 & 33 & 25 \\
\hline & $\mathrm{SiO}_{2}$ in slag $(\mathrm{kg} / \mathrm{t}$ steel $)$ & 37 & 31 & 22 & 16 & 18 & 11 \\
\hline & $\mathrm{Al}_{2} \mathrm{O}_{3}$ in slag $(\mathrm{kg} / \mathrm{t}$ steel $)$ & 1 & 1 & 4 & 4 & 4 & 4 \\
\hline & $\mathrm{CO}_{2}-\mathrm{Fe}$ material $(\mathrm{kg} / \mathrm{t}$ steel $)$ & 574 & 564 & 557 & 547 & 552 & 542 \\
\hline & $\mathrm{CO}_{2}$-EAF $(\mathrm{kg} / \mathrm{t}$ steel $)$ & 351 & 325 & 306 & 284 & 290 & 268 \\
\hline & $\mathrm{CO}_{2}$-total $(\mathrm{kg} / \mathrm{t}$ steel $)$ & 926 & 889 & 863 & 831 & 842 & 810 \\
\hline
\end{tabular}


Table 9 Production data for production case 3. Medium values for scrap are left out since the system shows a linear performance

Data DRI H + scrap H DRI H + scrap L DRI M + scrap H DRI M + scrap L DRI L + DRIL + scrap H scrap L

\begin{tabular}{|c|c|c|c|c|c|c|c|}
\hline \multirow{15}{*}{$\begin{array}{l}\text { Production case } 3,100 t \\
\text { steel DRI + } 80 \text { t scrap }\end{array}$} & DRI (kg/t steel) & 281 & 262 & 271 & 253 & 269 & 251 \\
\hline & Production cost $\mathrm{USD} / \mathrm{t}$ steel & 397 & 383 & 390 & 376 & 388 & 374 \\
\hline & Tap-to-tap time (min) & 65 & 61 & 63 & 60 & 62 & 59 \\
\hline & Slag amount (kg/t steel) & 118 & 80 & 98 & 60 & 91 & 53 \\
\hline & Electricity $(\mathrm{kWh} / \mathrm{t}$ steel $)$ & 495 & 461 & 478 & 446 & 472 & 440 \\
\hline & Lime $(\mathrm{kg} / \mathrm{t}$ steel $)$ & 16 & 13 & 15 & 12 & 15 & 12 \\
\hline & Dolomite $(\mathrm{kg} / \mathrm{t}$ steel) & 38 & 22 & 28 & 13 & 24 & 9 \\
\hline & $\mathrm{FeO}$ in slag (kg/t steel) & 23 & 16 & 19 & 12 & 18 & 11 \\
\hline & $\mathrm{MgO}$ in slag $(\mathrm{kg} / \mathrm{t}$ steel $)$ & 11 & 7 & 9 & 5 & 8 & 4 \\
\hline & $\mathrm{CaO}$ in slag $(\mathrm{kg} / \mathrm{t}$ steel $)$ & 45 & 30 & 37 & 23 & 34 & 20 \\
\hline & $\mathrm{SiO}_{2}$ in slag $(\mathrm{kg} / \mathrm{t}$ steel $)$ & 28 & 17 & 21 & 11 & 19 & 9 \\
\hline & $\mathrm{Al}_{2} \mathrm{O}_{3}$ in slag $(\mathrm{kg} / \mathrm{t}$ steel $)$ & 1 & 1 & 2 & 2 & 2 & 2 \\
\hline & $\mathrm{CO}_{2}-\mathrm{Fe}$ material $(\mathrm{kg} / \mathrm{t}$ steel $)$ & 269 & 252 & 261 & 244 & 259 & 241 \\
\hline & $\mathrm{CO}_{2}$-EAF (kg/t steel) & 307 & 270 & 287 & 252 & 280 & 245 \\
\hline & $\mathrm{CO}_{2}$-total $(\mathrm{kg} / \mathrm{t}$ steel $)$ & 576 & 522 & 548 & 496 & 538 & 487 \\
\hline
\end{tabular}

of lime and dolomite and losses of $\mathrm{FeO}$ to slag in production cases 1-3 as a result of a decrease in the $\mathrm{SiO}_{2}$ content in DRI by $2 \mathrm{pp}$ and a decrease in $\mathrm{Si}_{\text {tot }}$ in scrap by $0.3 \mathrm{pp}$ is presented. It can be seen that the high slag volumes discussed above are to a great extent caused by the necessity to add dolomite to avoid an aggressive slag.

The reductions in dolomite additions for DRI and scrap are $33 \mathrm{~kg} / \mathrm{t}, 22 \mathrm{~kg} / \mathrm{t}$ and $16 \mathrm{~kg} / \mathrm{t}$ respectively for the three cases, respectively. Since the dolomite contains a high amount of $\mathrm{CaO}$, the lime addition is not affected that much and differs by only $0.8 \mathrm{~kg} / \mathrm{t}, 1.9 \mathrm{~kg} / \mathrm{t}$ and $2.5 \mathrm{~kg} / \mathrm{t}$ in the three cases, respectively. Furthermore, the decrease in the loss of $\mathrm{FeO}$ to the slag is 12,6 and $7 \mathrm{~kg} / \mathrm{t}$ steel for the three cases, respectively.

The calculations in this work are based on a DRI production using natural gas and an electricity grid mix of $0.49 \mathrm{~kg} /$ $\mathrm{kWh}$. Figure 4 shows the reduction of $\mathrm{CO}_{2}$ emissions as a function of a decreased $\mathrm{SiO}_{2}$ content in DRI by $2 \mathrm{pp}$ and a decreased $\mathrm{Si}_{\text {tot }}$ content in scrap by $0.3 \mathrm{pp}$ for the production cases 1-3. The decrease in $\mathrm{CO}_{2}$ emissions origins from decreased consumption of DRI due to the lower loss of iron in $\mathrm{FeO}$ shown in the bar for $\mathrm{Fe}$ material, and decreased

Table 10 Dependence of $\mathrm{Si}$ in DRI and scrap on slag volume

\begin{tabular}{llll}
\hline \multicolumn{4}{l}{ Parameters referring to Eq. 2} \\
\hline & $a$ & $b$ & $c$ \\
\hline Case 1 & 28.8 & 14.9 & 33.7 \\
Case 2 & 18.5 & 38.4 & 28.8 \\
Case 3 & 8.4 & 63.6 & 22.4 \\
\hline
\end{tabular}

consumption of dolomite and electricity shown in the bar for the EAF. The total reductions of $\mathrm{CO}_{2}$ in the three cases are 88, 67 and $49 \mathrm{~kg} \mathrm{CO}_{2} / \mathrm{t}$ steel, respectively.

\section{Benefit analysis of ore beneficiation and scrap upgrade}

The calculation results presented in Table 11 show that a conservative estimation of the benefit of decreasing the silica content in DRI by 2 pp is $20 \mathrm{USD} / \mathrm{t}$ DRI or $15 \mathrm{USD} / \mathrm{t} \mathrm{DR}$ pellets and a conservative figure for the benefit of decreasing the dirt in scrap by $0.3 \mathrm{pp} \mathrm{Si}$ tot is $9 \mathrm{USD} / \mathrm{t}$ scrap. The corresponding reduction of slag volume is on average $63 \mathrm{~kg} / \mathrm{t}$ DRI or $47 \mathrm{~kg} / \mathrm{t}$ DR pellets and $24 \mathrm{~kg} / \mathrm{t}$ scrap. The reduced slag volume results in a decrease in the iron losses by $9.6 \mathrm{~kg} / \mathrm{t}$ DRI or $7.1 \mathrm{~kg} / \mathrm{t}$ DR pellets and $3.5 \mathrm{~kg} / \mathrm{t} \mathrm{scrap}$. Finally, the $\mathrm{CO}_{2}$ emissions are reduced by $84 \mathrm{~kg} / \mathrm{t}$ DRI or $62 \mathrm{~kg} / \mathrm{t}$ DR pellets and $34 \mathrm{~kg} / \mathrm{t}$ scrap.

Production costs for the three plant types discussed in this paper are shown in Figs. 5, 7 and 9. Guidelines for 2\%, 3\% and $4 \% \mathrm{SiO}_{2}$ in DRI are introduced in the figures. Furthermore, cost savings due to a decrease in the $\mathrm{SiO}_{2}$ content in DRI by 2 pp (amber arrows) and the $\mathrm{Si}_{\text {tot }}$ content in scrap by $0.3 \mathrm{pp}$ (blue arrows) are indicated in the figures.

\section{Production case 1: integrated DR-EAF plant}

For an integrated DR plant, an ore beneficiation and scrap upgrading according to the example results in a total saving of $24 \mathrm{USD} / \mathrm{t}$ steel when the $\mathrm{Si}_{\text {tot }}$ in scrap and $\mathrm{SiO}_{2}$ in DRI are reached to $0.5 \%$ and 2\%, respectively, as shown in Fig. 5. 
Table 11 Benefits calculated for production cases 1-3 when decreasing the $\mathrm{SiO}_{2}$ content in DR pellets by $2 \mathrm{pp}$ and the $\mathrm{Si}_{\text {tot }}$ in scrap by $0.3 \mathrm{pp}$

\begin{tabular}{|c|c|c|c|c|c|c|}
\hline \multirow[t]{2}{*}{ Production case 1} & \multicolumn{2}{|l|}{$\mathrm{DRI}^{1}$} & \multirow{2}{*}{$\begin{array}{l}\text { DR pellets }{ }^{2} \\
/ \mathrm{t} \text { pellets }\end{array}$} & \multicolumn{2}{|l|}{ Scrap $^{3}$} & \multirow{2}{*}{$\begin{array}{l}\text { Total } \\
\text { /t steel }\end{array}$} \\
\hline & $/ \mathrm{t}$ steel & $/ \mathrm{t}$ DRI & & $/ \mathrm{t}$ steel & $/ \mathrm{t}$ scrap & \\
\hline Cost saving (USD) & 22 & 24 & 18 & 2 & 11 & 24 \\
\hline Decreased slag amount (kg) & 57 & 63 & 47 & 5 & 24 & 62 \\
\hline Decreased iron loss (kg Fe) & 8.8 & 9.8 & 7.2 & 0.7 & 3.5 & 9.5 \\
\hline Decreased $\mathrm{CO}_{2}$ emission $(\mathrm{kg})$ & 81 & 90 & 67 & 7 & 35 & 88 \\
\hline \multirow[t]{2}{*}{ Production case 2} & DRI & & DR pellets & Scrap & & Total \\
\hline & $/ \mathrm{t}$ steel & $/ \mathrm{t} \mathrm{DRI}$ & $/ \mathrm{t}$ pellets & $/ \mathrm{t}$ steel & $/ \mathrm{t}$ scrap & $/ \mathrm{t}$ steel \\
\hline Cost saving (USD) & 12 & 21 & 16 & 6 & 11 & 18 \\
\hline Decreased slag amount (kg) & 36 & 63 & 46 & 12 & 24 & 48 \\
\hline Decreased iron loss ( $\mathrm{kg} \mathrm{Fe})$ & 5.6 & 9.7 & 7.2 & 1.9 & 3.8 & 7.4 \\
\hline Decreased $\mathrm{CO}_{2}$ emission $(\mathrm{kg})$ & 49 & 85 & 63 & 18 & 36 & 67 \\
\hline \multirow[t]{2}{*}{ Production case 3} & DRI & & DR pellets & Scrap & & Total \\
\hline & $/ \mathrm{t}$ steel & $/ \mathrm{t}$ DRI & $/ \mathrm{t}$ pellets & $/ \mathrm{t}$ steel & $/ \mathrm{t}$ scrap & /t steel \\
\hline Cost saving (USD) & 5 & 20 & 15 & 7 & 9 & 13 \\
\hline Decreased slag amount $(\mathrm{kg})$ & 17 & 63 & 47 & 19 & 24 & 36 \\
\hline Decreased iron loss (kg Fe) & 2.5 & 9.6 & 7.1 & 3.0 & 3.8 & 5.5 \\
\hline Decreased $\mathrm{CO}_{2}$ emission $(\mathrm{kg})$ & 22 & 84 & 62 & 27 & 34 & 49 \\
\hline
\end{tabular}

${ }^{1}$ DRI amounts are set to $900 \mathrm{~kg} / \mathrm{t}$ steel, $580 \mathrm{~kg} / \mathrm{t}$ steel and $260 \mathrm{~kg} / \mathrm{t}$ steel for production case 1 , case 2 and case 3, respectively, by interpolating the DRI amounts presented in Tables 7,8 and 9 to $2 \% \mathrm{SiO}_{2} \mathrm{DRI}$ and $0.5 \% \mathrm{Si}_{\text {tot }}$ in scrap

${ }^{2}$ The mass ratio is assumed as pellet/DRI $=1.35$

${ }^{3}$ Scrap amount in production cases 1,2 and 3 is $200 \mathrm{~kg} / \mathrm{t}$ steel, $500 \mathrm{~kg} / \mathrm{t}$ steel and $800 \mathrm{~kg} / \mathrm{t}$ steel, respectively
Here, $22 \mathrm{USD} / \mathrm{t}$ of steel stems from the DRI product. A plant that is operated according to production case 1 would normally only use internal scrap. Thus, sand and dirt in scrap would then come from the steel plant scrap yard, which would be possible to control if the issue is recognized by the process management.
In Fig. 6, Eq. 2 is used to show the relationship between the $\mathrm{Si}_{\text {tot }}$ in scrap, $\mathrm{SiO}_{2}$ in DRI and the slag volume for an integrated steel plant as described by case 1 . The volume corresponding to $100 \mathrm{~kg} / \mathrm{t}$ is marked in red. For a scrap with an $\mathrm{Si}_{\text {tot }}$ content of $0.5 \%$, the slag amount reaches $100 \mathrm{~kg} / \mathrm{t}$ steel just below a content of $2 \% \mathrm{SiO}_{2}$ in DRI or $1.5 \%$ in DR pellets and
Table 12 Data for upgrading a haematite concentrate consisting of a main part with $67 \% \mathrm{Fe}$ and $1 \% \mathrm{SiO}_{2}$ and an $\mathrm{SiO}_{2}$-rich fraction with $70 \% \mathrm{SiO}_{2}$ and (A) $10 \% \mathrm{Fe}$, (B) $15 \% \mathrm{Fe}$ and (C) $20 \%$ $\mathrm{Fe}$ which is possible to remove in an extra beneficiation operation

\begin{tabular}{|c|c|c|c|c|c|c|}
\hline \multirow[t]{2}{*}{ Ores } & & \multicolumn{5}{|c|}{$\mathrm{SiO}_{2}$-rich fraction (\%) } \\
\hline & & 0 & 1 & 2 & 3 & 4 \\
\hline All ores & $\mathrm{SiO}_{2}$ content in concentrate before beneficiation $(\%)$ & 1.00 & 1.69 & 2.38 & 3.07 & 3.76 \\
\hline \multirow[t]{4}{*}{ Main + A } & Fe content in concentrate before beneficiation $(\%)$ & 67.00 & 66.43 & 65.86 & 65.29 & 64.72 \\
\hline & Iron value in ore based on $80 \mathrm{c} / \mathrm{u}(\mathrm{USD} / \mathrm{t})$ & 53.60 & 53.14 & 52.69 & 52.23 & 51.78 \\
\hline & Iron loss when upgrading ( $\mathrm{kg} \mathrm{Fe} / \mathrm{t}$ concentrate) & 0 & 1.01 & 2.04 & 3.09 & 4.17 \\
\hline & Iron loss when upgrading (USD/t concentrate) & 0 & 0.08 & 0.16 & 0.25 & 0.33 \\
\hline \multirow[t]{4}{*}{ Main + B } & Fe content in concentrate before beneficiation (\%) & 67.00 & 66.48 & 65.96 & 65.44 & 64.92 \\
\hline & Iron value in ore based on $80 \mathrm{c} / \mathrm{u}(\mathrm{USD} / \mathrm{t})$ & 53.60 & 53.18 & 52.77 & 52.35 & 51.94 \\
\hline & Iron loss when upgrading ( $\mathrm{kg} \mathrm{Fe} / \mathrm{t}$ concentrate) & 0 & 1.52 & 3.06 & 4.64 & 6.25 \\
\hline & Iron loss when upgrading (USD/t concentrate) & 0 & 0.12 & 0.24 & 0.37 & 0.50 \\
\hline \multirow[t]{4}{*}{ Main $+\mathrm{C}$} & Fe content in concentrate before beneficiation (\%) & 67.00 & 66.53 & 66.06 & 65.59 & 65.12 \\
\hline & Iron value in ore based on $80 \mathrm{c} / \mathrm{u}(\mathrm{USD} / \mathrm{t})$ & 53.60 & 53.22 & 52.85 & 52.47 & 52.10 \\
\hline & Iron loss when upgrading ( $\mathrm{kg} \mathrm{Fe} / \mathrm{t}$ concentrate) & 0 & 2.02 & 4.08 & 6.19 & 8.33 \\
\hline & Iron loss when upgrading (USD/t concentrate) & 0 & 0.16 & 0.33 & 0.49 & 0.67 \\
\hline
\end{tabular}


$=\operatorname{DRI}\left(\Delta=2 p p \mathrm{SiO}_{2}\right) \quad \square \operatorname{Scrap}\left(\Delta=0.3 p p \mathrm{Si}_{\text {tot }}\right)$

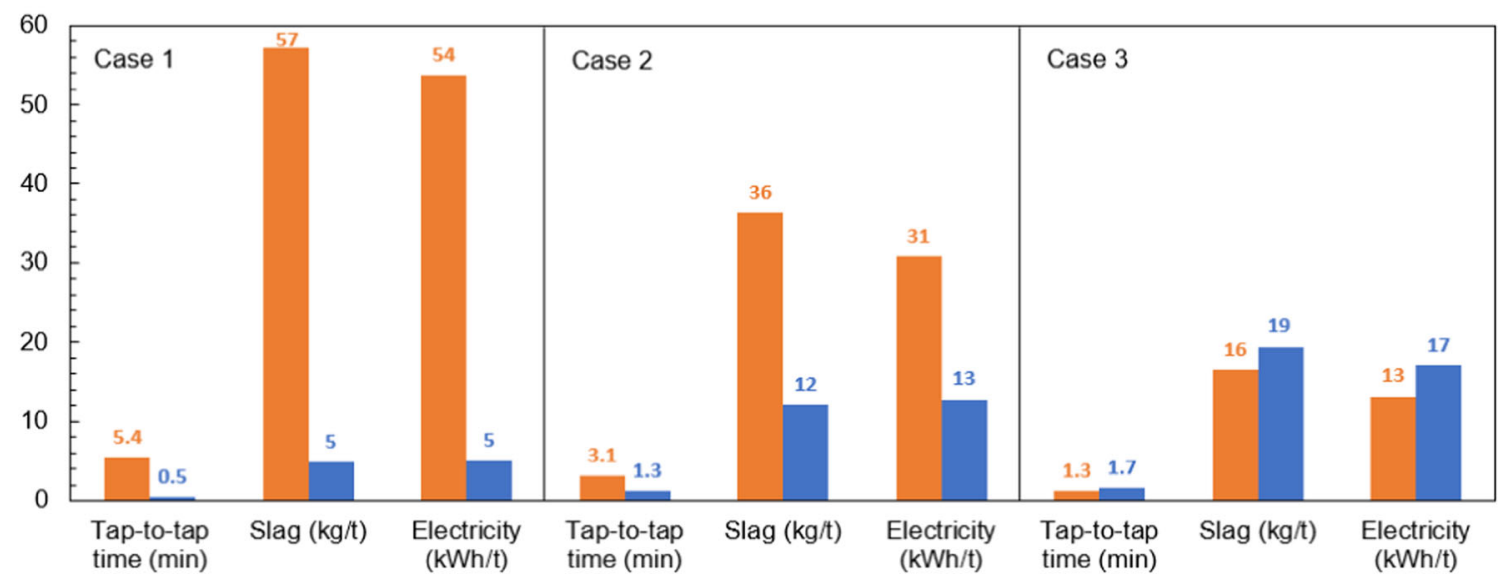

Fig. 2 Reduction of tap-to-tap time, slag amount and electricity consumption in production cases 1-3 as a result of a decrease in $\mathrm{SiO}_{2}$ content in $\mathrm{DRI}$ by $2 \mathrm{pp}$ and a decrease in $\mathrm{Si}_{\text {tot }}$ in scrap by $0.3 \mathrm{pp}$

reaches $160 \mathrm{~kg} / \mathrm{t}$ steel below a content of $4 \% \mathrm{SiO}_{2}$ in DRI or $3 \%$ in DR pellets.

\section{Production case 2: EAF plant with continuous charging of $\mathrm{DRI} / \mathrm{HBI}$ instead of second basket}

Figure 7 shows the cost saving in production case $2(100 \mathrm{t}$ steel from 50 t scrap + rest DRI) when $\mathrm{SiO}_{2}$ in DRI is decreased by 2 pp and $\mathrm{Si}_{\text {tot }}$ in scrap is decreased by $0.3 \mathrm{pp}$. For an EAF plant using comparable amounts of scrap and DRI/ $\mathrm{HBI}$, an ore beneficiation and scrap upgrading according to the example results in a total saving of $18 \mathrm{USD} / \mathrm{t}$ steel. Here, $12 \mathrm{USD} / \mathrm{t}$ steel stems from improvements in the DRI quality. The slag amount reaches $100 \mathrm{~kg} / \mathrm{t}$ steel below a $3 \% \mathrm{SiO}_{2}$ content in DRI or a $2.2 \% \mathrm{SiO}_{2}$ content in DR pellets for a scrap with $0.5 \% \mathrm{Si}_{\text {tot }}$ content, as can be seen from Fig. 8 .

\section{Production case 3: EAF plant with $\mathrm{DRI} / \mathrm{HBI}$ as an addition}

Figure 9 shows the cost saving of production case $3(100 \mathrm{t}$ steel from $80 \mathrm{t}$ scrap + rest DRI), when the $\mathrm{SiO}_{2}$ content in DRI is decreased by $2 \mathrm{pp}$ and the $\mathrm{Si}_{\text {tot }}$ content in scrap is decreased by 0.3 pp. For an EAF plant with only a minor addition of DRI/HBI, an ore beneficiation and scrap upgrading according to the example results in a total saving of $12 \mathrm{USD} / \mathrm{t}$ steel. The improvement due to a scrap upgrade has a slightly higher impact on the production cost than an improvement of the DRI quality.

Figure 10 shows the slag volumes in production case 3 as a function of the $\% \mathrm{SiO}_{2}$ content in DRI and the $\mathrm{Si}_{\text {tot }}$ content in scrap. The slag amounts displayed illustrate that it is possible to use a DRI content of up to $5 \% \mathrm{SiO}_{2}$ before reaching $100 \mathrm{t}$ slag/t steel when charging scrap with an $\mathrm{Si}_{\text {tot }}$ content of $0.5 \%$. For a clean scrap with an $\mathrm{Si}_{\text {tot }}$ of $0.3 \%$, the slag volume stays under $60 \mathrm{~kg} / \mathrm{t}$ steel with a DRI of $2 \% \mathrm{SiO}_{2}$.

\section{Cost analysis of iron losses due to an ore beneficiation and a scrap upgrade}

The value of iron lost in an extra beneficiation operation is shown in Fig. 11 for three hypothetical cases A-C for tailing grades of (A) $10 \% \mathrm{Fe},(\mathrm{B}) 15 \% \mathrm{Fe}$ and (C) $20 \% \mathrm{Fe}$, which all

= $\operatorname{DRI}\left(\Delta=2 p p \mathrm{SiO}_{2}\right) \quad \operatorname{Scrap}\left(\Delta=0.3 p p \mathrm{Si}_{\text {tot }}\right)$

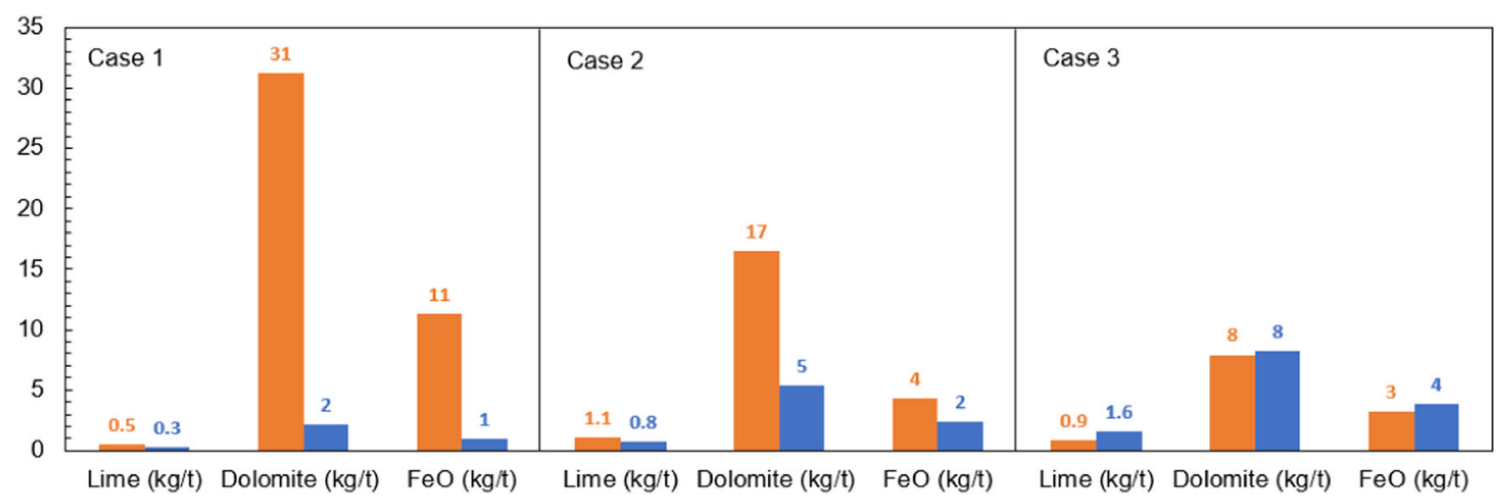

Fig. 3 Reduction of consumption of lime and dolomite and losses of $\mathrm{FeO}$ to slag in production cases 1-3 as a result of a decrease in $\mathrm{SiO}_{2}$ content in DRI by $2 \mathrm{pp}$ and a decrease in $\mathrm{Si}_{\text {tot }}$ in scrap by $0.3 \mathrm{pp}$ 
$=\mathrm{DRI}\left(\Delta=2 \mathrm{pp} \mathrm{SiO}{ }_{2}\right) \quad=\mathrm{Scrap}\left(\Delta=0.3 \mathrm{pp} \mathrm{Si} \mathrm{itt}_{\text {tot }}\right)$

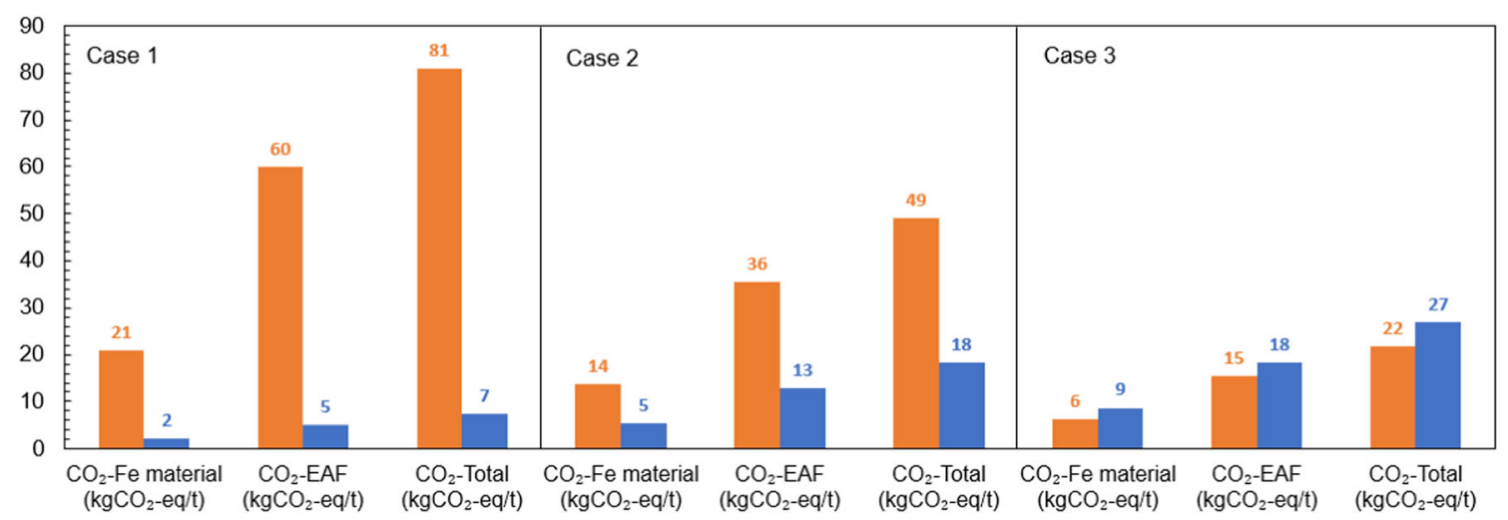

Fig. 4 Reduction of $\mathrm{CO}_{2}$ emissions in production cases 1-3 as a result of a decrease in $\mathrm{SiO}_{2}$ content in DRI by 2 pp and a decrease in $\mathrm{Si}_{\text {tot }}$ in scrap by 0.3 pp

contain $70 \% \mathrm{SiO}_{2}$. Data from the calculations are given in Table 12. The iron content in the beneficiated ore is $67 \%$. The iron content of the ores before beneficiation varies between 66.4 and $64.7 \%$ of fraction A, 66.5 to $64.9 \%$ for fraction $\mathrm{B}$ and 66.5 to $65.1 \%$ for fraction C. A decrease in the $\mathrm{SiO}_{2}$ content by 2 pp result in the following Fe losses in the three cases: $3 \mathrm{~kg} / \mathrm{t}$ or $0.24 \mathrm{USD} / \mathrm{t}$ for case $\mathrm{A}, 4.5 \mathrm{~kg} / \mathrm{t}$ or $0.36 \mathrm{USD} / \mathrm{t}$ for case $\mathrm{B}$ and $6 \mathrm{~kg} / \mathrm{t}$ or $0.47 \mathrm{USD} / \mathrm{t}$ for case $\mathrm{C}$.

The indicative CAPEX + OPEX values for an additional beneficiation operation are assumed to be $2 \mathrm{USD} / \mathrm{t}$, which indicate an upgrading cost of around 2.5 USD/t when decreasing the $\mathrm{SiO}_{2}$ level by $2 \mathrm{pp}$. The same value may be used for the produced DR pellets, since only small additions are made to the pellet feed in the pelletization process.

Assuming an iron loss between 0.1 and $0.5 \%$ in the scrap upgrading depending on the scrap and upgrading process results in an iron loss of between 1 and $5 \mathrm{~kg} / \mathrm{t}$ for the upgraded scrap. The cost for the iron loss would be between 0.22 and 1.1 USD/t. The indicative CAPEX + OPEX values for an additional assumed upgrading operation of scrap of $1 \mathrm{USD} / \mathrm{t}$ indicate an upgrading cost of around 1.22-2.1 USD/t based on calculations using Eq. 1.

\section{Cost benefit analysis}

Bearing in mind that the CAPEX + OPEX values given for both ore beneficiation and scrap upgrading are only indicative and vary with ore and scrap properties, time and local conditions, the following attempt to provide a cost benefit analysis is made.

The benefit of an ore beneficiation resulting in a decreased $\mathrm{SiO}_{2}$ content in the pellets by $2 \mathrm{pp}$ is according to the "Benefit analysis of ore beneficiation and scrap upgrade" section more than $15 \mathrm{USD} / \mathrm{t}$ DR pellets. Assuming the highest cost calculated in the "Cost analysis of iron losses due to an ore beneficiation and a scrap upgrade" section, this gives a net benefit of 12.5 USD/t DR pellets.

For scrap, the benefit from a scrap upgrade and a proper scrap yard handling that leads to a decreased dirt fraction by $0.3 \mathrm{pp}$ of $\mathrm{Si}_{\text {tot }}$ was estimated to correspond to $9 \mathrm{USD} / \mathrm{t}$ scrap in the "Benefit analysis of ore beneficiation and scrap upgrade" section. Assuming the highest cost calculated in the "Cost analysis of iron losses due to an ore beneficiation and a scrap upgrade" section, this gives a net benefit of 6.9 to $7.8 \mathrm{USD} / \mathrm{t}$ scrap. A conservative approach assuming a decrease of $0.1 \mathrm{pp}$
Fig. 5 Cost saving of production case 1 (100 $t$ steel from $20 t$ scrap + rest DRI) when $\mathrm{SiO}_{2}$ in DRI is decreased by 2 pp and $\mathrm{Si}_{\text {tot }}$ in scrap is decreased by $0.3 \mathrm{pp}$

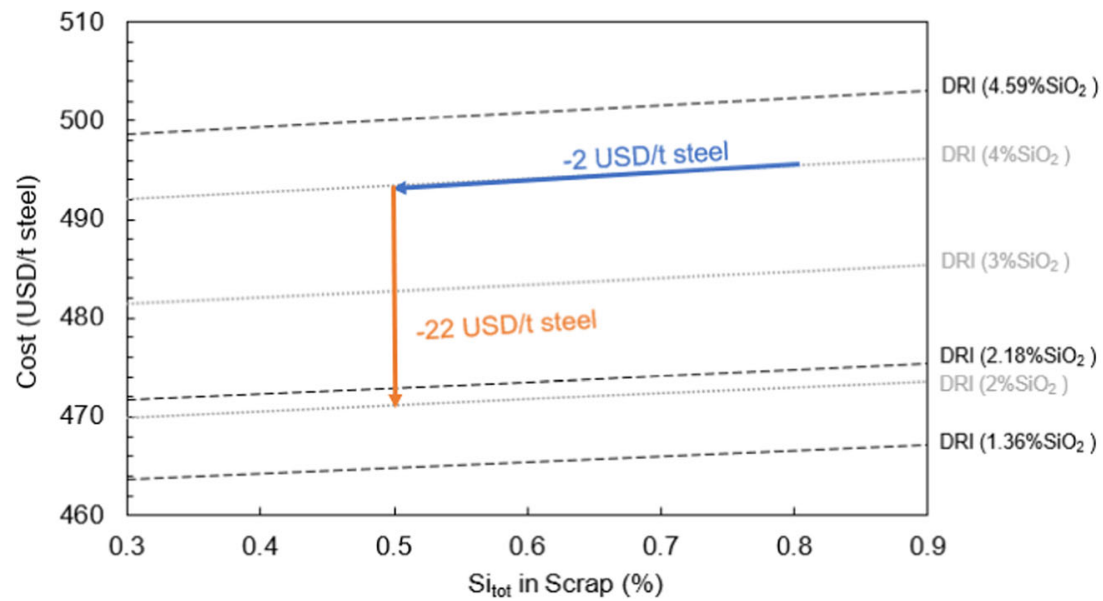


Fig. 6 Slag volumes in production case 1 as a function of $\% \mathrm{SiO}_{2}$ in DRI and $\% \mathrm{Si}_{\text {tot }}$ in scrap

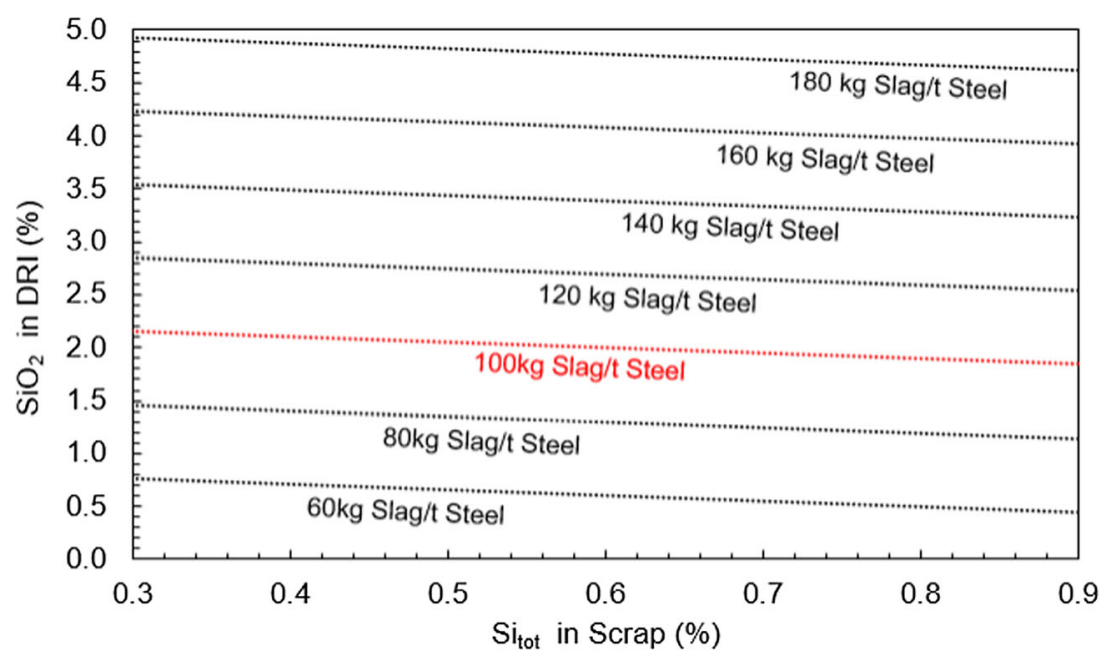

Si would give a benefit of 3 USD/t scrap and a net benefit of more moderate $0.9-1.78 \mathrm{USD} / \mathrm{t}$ scrap.

\section{Discussion}

Reaching the goal to become carbon neutral in the future will demand vast investments in new technologies and renewed capacities in the steel industry. As BF-BOF plants in the western world are ageing and costs for emitting $\mathrm{CO}_{2}$ are increasing, new solutions are sought. The DR-EAF route is favoured among a number of steel companies as the main process route to improve sustainability. Therefore, a drastically increased DRI capacity is expected within the next decades.

\section{Benefits and costs, resource conservation and $\mathrm{CO}_{2}$-emission abatement}

The cost benefit analysis in the previous section indicates that the benefit from ore beneficiation widely exceeds the costs, based on the given assumptions for the DRI. In addition, even with a conservative approach, the cost is in parity for scrap upgrading. For both materials, other benefits may be obtained such as a decreased phosphorus content due to the ore beneficiation and decreased copper contents due to an improved scrap upgrading.

From a resource conservation perspective, the iron loss in

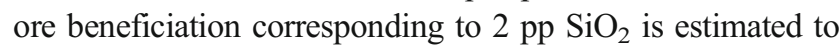
have a value of $6 \mathrm{~kg} / \mathrm{t}$ pellet feed. This is in the same range as the estimated iron loss to an EAF slag without beneficiation, which is estimated to $7.1 \mathrm{~kg} / \mathrm{t}$ pellets. However, the main difference with respect to the resource consumption is the decreased use of dolomite and energy. The amount of resources consumed in the beneficiation step, mainly electricity, grinding media and flotation reagents, is highly dependent on the ore beneficiated. This aspect is not discussed in this paper. Studies made for specific ores should however include the increase in this resource use.

Iron loss from scrap upgrade depends on the scrap itself and the machinery deployed. When decreasing dirt in scrap by $0.3 \mathrm{pp} \mathrm{Si}_{\text {tot }}$, the reduction of slag lost to an EAF slag is $3.5 \mathrm{~kg}$
Fig. 7 Cost saving in production case 2 (100 $t$ steel from $50 \mathrm{t}$ scrap + rest DRI) when $\% \mathrm{SiO}_{2}$ in DRI is decreased by $2 \mathrm{pp}$ and $\% \mathrm{Si}_{\text {tot }}$ in scrap is decreased by $0.3 \mathrm{pp}$

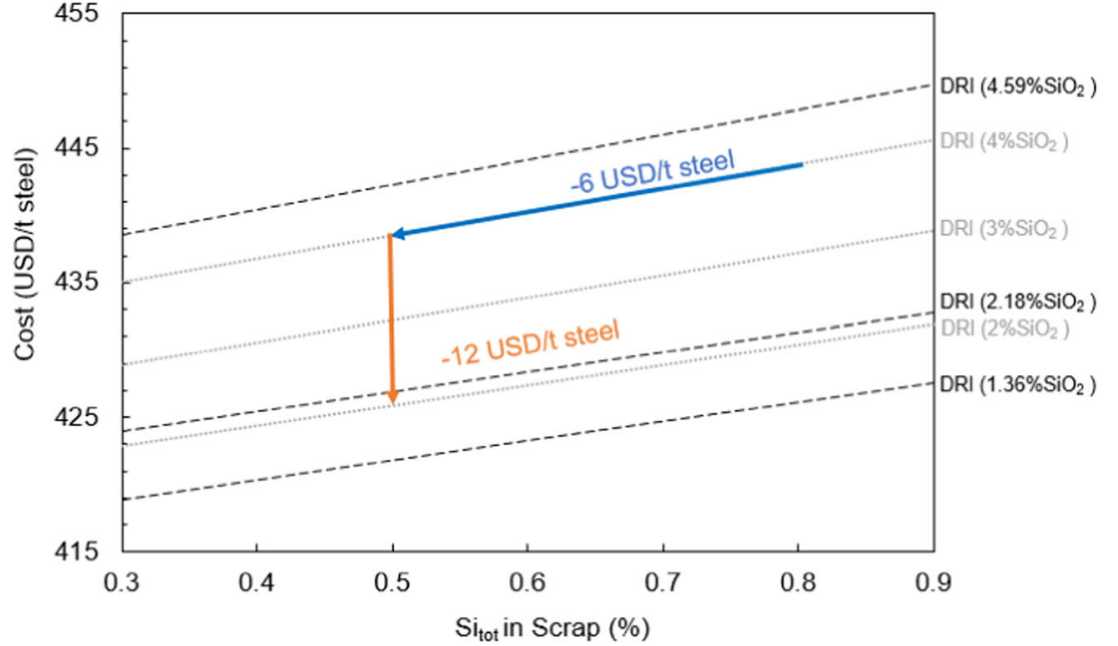


Fig. 8 Slag volumes in production case 2 depending on $\% \mathrm{SiO}_{2}$ in $\mathrm{DRI}$ and $\% \mathrm{Si}_{\text {tot }}$ in scrap

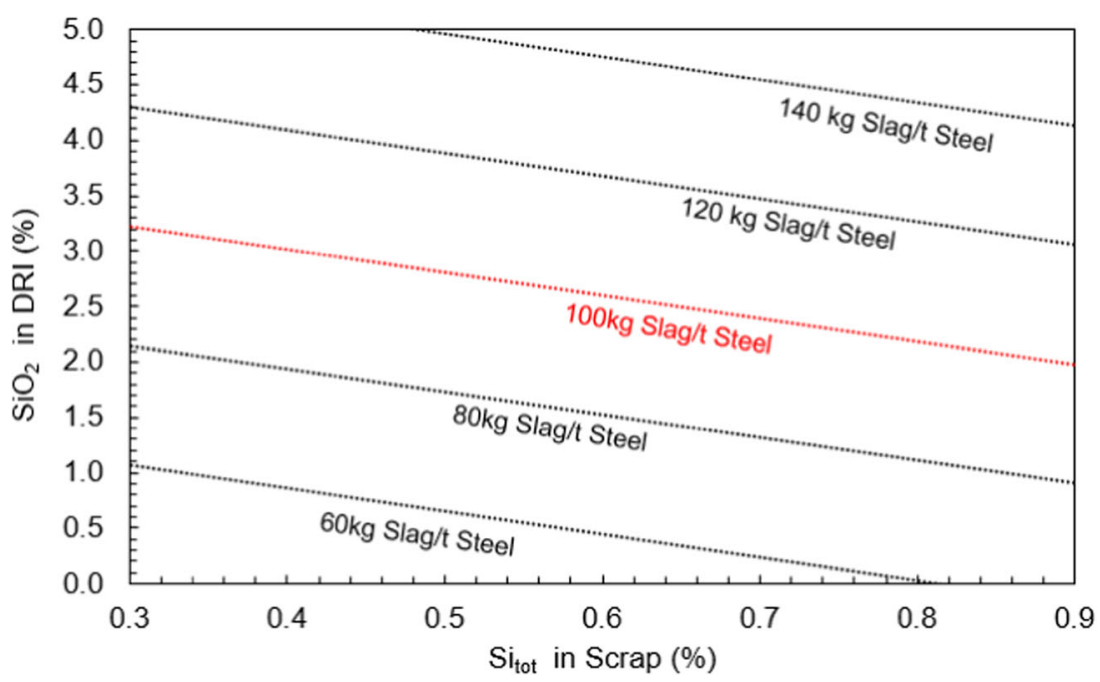

Fe/t scrap. This value can be compared to the example data in the "Cost analysis of iron losses due to an ore beneficiation and a scrap upgrade" section of $1-5 \mathrm{~kg}$ Fe/t scrap lost due to the scrap upgrading. It should again be mentioned that scrap upgrading also is carried out due to other reasons such as for the removal of other metals and materials. The operation mainly consumes electricity and machine spare parts, which is left out of this study but should be included when studying any specific scrap upgrading flow.

The effect on $\mathrm{CO}_{2}$ emissions with a decrease between 88 and $49 \mathrm{~kg} \mathrm{CO}_{2} / \mathrm{t}$ steel is relevant in a situation where the costs for emissions increase and the environmental performance is an important part of a product profile.

Since the resource conservation advantages and $\mathrm{CO}_{2}$ mitigation come without extra cost, they should be emphasized in the debate and serve as an additional argument for decreasing the content of silica in DR pellets, DRI/HBI and scrap.

The economic and environmental benefits outlined in this general paper must however be verified with case studies where the beneficiation properties of the ores such as the hardness and tailing grade are taken into account when calculating the beneficiation costs. For the benefit side, a full chemical composition determination of the ore and the additions to the pellet feed would give a more precise picture of the slag properties in the EAF. For scrap, publicly shared quality data as well as methods to estimate the scrap quality by evaluating process data from the EAF would make a big difference for the possibilities to negotiate a quality premium or discount, or deciding on investment in upgrading equipment and scrap yard facilities.

\section{Migration from BF-BOF route to DR-EAF route}

As stated above, a technology shift where $25 \%$ of the global pig iron production is replaced by DRI production creates an increased demand for additional DR-grade pellets by up to $448 \mathrm{Mt}$. In the more conservative shift where $5 \%$ of the pig iron is replaced, it was stated an additional $90 \mathrm{Mt}$ of new DRgrade pellet capacity is needed.
Fig. 9 Cost saving of production case 3 (100 t steel from $80 \mathrm{t}$ scrap + rest DRI) when $\% \mathrm{SiO}_{2}$ in DRI is decreased by $2 \mathrm{pp}$ and $\% \mathrm{Si}_{\text {tot }}$ in scrap is decreased by $0.3 \mathrm{pp}$

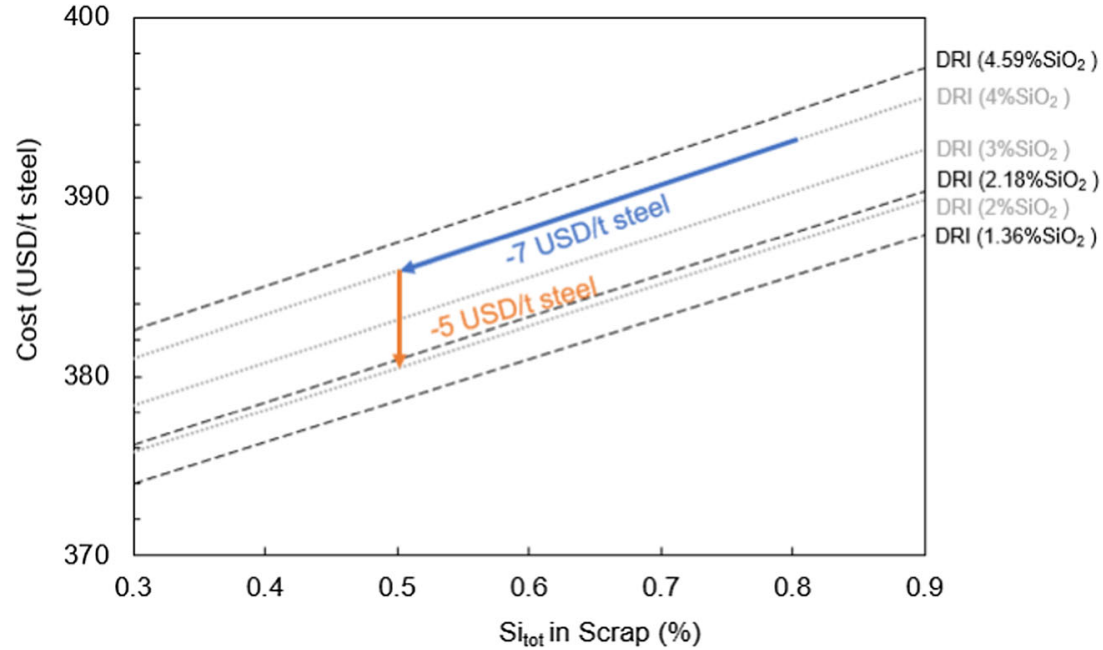


Fig. 10 Slag volumes in production case 3 depending on $\% \mathrm{SiO}_{2}$ in $\mathrm{DRI}$ and $\% \mathrm{Si}_{\text {tot }}$ in scrap

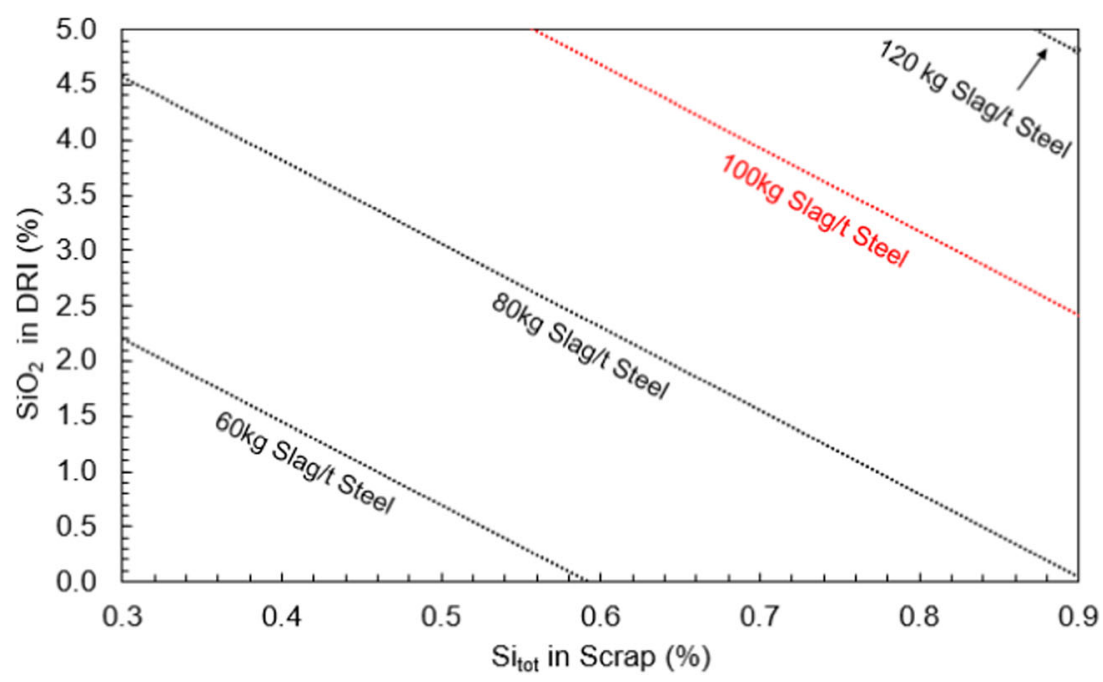

With an investment period of 30 years to 2050 , investments in this new capacity where BF-pellet feed and sinter fines are beneficiated to DR-pellet concentrate grade must be made at a high pace. About a $15 \mathrm{Mt}$ capacity per year must be created for the $25 \%$ alternative and $3 \mathrm{Mt} /$ year for the $5 \%$ alternative. The demand for extra pelletizing capacities depends on the amount of the existing BF-pellet capacities that migrate to the DRpellet capacity.

Two factors of importance are the size and diversity of the DRI market and the structure of the supply chain. Assuming that stability is favoured by a large number of diverse DRI users, it seems reasonable to think that an increased number of plants such as production cases 2 and 3 would serve that purpose. However, that would require an increased number of merchant DRI suppliers that has to emerge in the future. Several scenarios are possible, but a strong engagement from the ore suppliers is necessary to assess a stable supply of DR-grade pellets in the future.

\section{Conclusion}

The aim of this paper is to show the importance of raw material quality to a successful migration from the BF-BOF route to the DR-EAF route in order to reach global climate goals. In order to promote investments in ore beneficiation and scrap upgrade, it provides a basis to calculate a potential improvement in revenue. An obstacle highlighted in the article and displayed in Fig. 1 is that costs and benefits appear in different parts of the supply chain.

- Calculations were made by using the optimization and calculation tool RAWMATMIX® for three commercial DR pellets with varying $\mathrm{SiO}_{2}$ content and three hypothetical scrap types with varying $\mathrm{Si}_{\text {tot }}$ representing the level of dirt.

- The following three plant types were studied: (i) an integrated DR-EAF plant using internal scrap, (ii) a plant using equal amounts of scrap and DRI and (iii) a plant
Fig. 11 Iron loss in USD/t and $\mathrm{kg} / \mathrm{t}$ processed concentrate when decreasing the $\mathrm{SiO}_{2}$ content by removing a fraction with $70 \%$ $\mathrm{SiO}_{2}$ and $\mathrm{A}: 10 \% \mathrm{Fe}$ (blue), $\mathrm{B}$ : $15 \% \mathrm{Fe}$ (amber) and C: $20 \% \mathrm{Fe}$ (green). The remaining haematite concentrate has $67 \% \mathrm{Fe}$ and $1 \%$ $\mathrm{SiO}_{2}$
Iron Loss (USD/t concentrate) Iron Loss (kg/t concentrate)

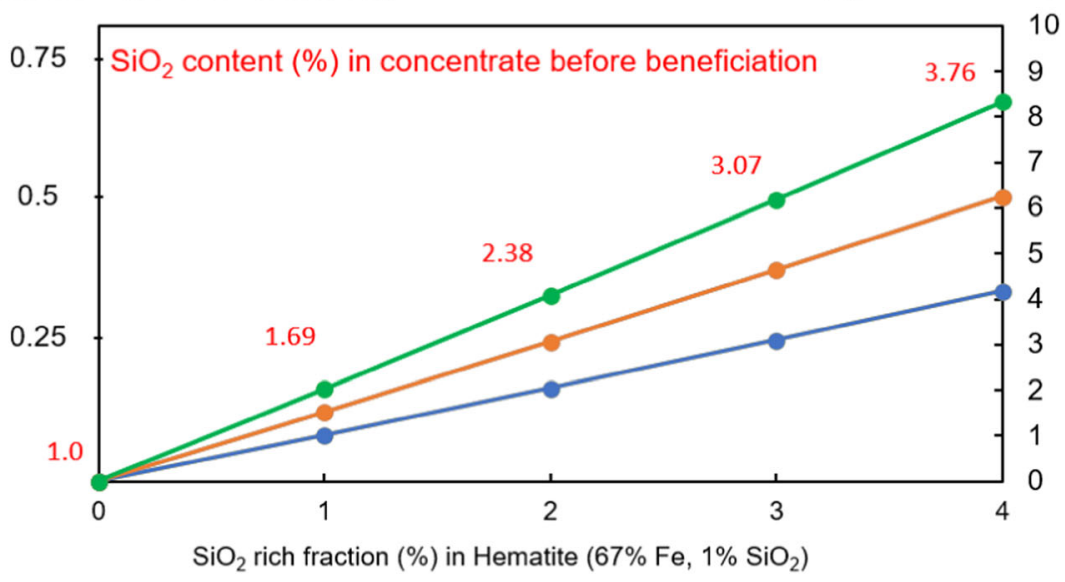

SiO2-rich fraction with A) $\left.\left.10 \% \mathrm{Fe}, 70 \% \mathrm{SiO}_{2} \mathrm{~B}\right) 15 \% \mathrm{Fe}, 70 \% \mathrm{SiO}_{2} \mathrm{C}\right) 20 \% \mathrm{Fe}, 70 \% \mathrm{SiO}_{2}$ 
using a smaller fraction of DRI in relation to the scrap amount.

- The impact on key process factors and the resulting economic value for an EAF plant to reduce the $\mathrm{SiO}_{2}$ content in DRI by 2 percentage points and the dirt content of scrap by 0.3 percentage points $\mathrm{Si}_{\text {tot }}$ were estimated.

- For each plant type, the slag volumes depending on the silica input were studied and requirements on raw materials to have a production under $100 \mathrm{~kg} \mathrm{slag} / \mathrm{t}$ steel were determined.

- An estimation of the beneficiation costs of ore and upgrading cost of scrap was made and the costs were compared with the benefits.

The overall conclusions are as follows:

- The loss of iron units in ore beneficiation is compensated for with higher savings in the EAF together with reduced consumption of slag formers.

- The benefit to the DR-EAF route of ore beneficiation to decrease the silica content is substantial given the tailing grade and a high and stable DR-grade premium based on actual pellet analysis would probably promote continuous investment to meet a higher demand.

- Estimating the benefit of scrap upgrade is less straight forward than for ore due to lagging data, but scrap upgrading should be important to keep the slag volumes at a minimum when the DRI fraction increases.

- Plants with a higher amount of scrap compared to DRI are more resilient to fluctuations in silica levels due to the lower slag amount and may have an advantage to integrated DR-EAF plants if the ore quality deteriorates in the future.

The more specific conclusions from this paper may be summarized as follows:

- The environmental benefit that comes with no extra cost is linked to a decreased slag generation, resulting in lower energy and resource consumption and as a consequence a lower $\mathrm{CO}_{2}$ emission.

- Though the generalizations in this paper made it possible to describe the area, detailed case studies should be made for specific scenarios. In these, it is important to take into consideration the beneficiation properties of individual ores and the impact of all gangue elements and additions made in pelletization. For scrap, more work has to be done on cost and benefit of individual upgrading cases. At the end, different plant locations and plant types should be studied in detail to assess the viability in the idea of replacing a substantial part of the production in the $\mathrm{BF}-\mathrm{BOF}$ route with production in the DR-EAF route.
- Finally, a stable DR-grade pellet supply is of greatest importance to make it possible for a substantial part of the steel production in the BF-BOF route to migrate to the DR-EAF route over the next 30 years. It is argued that in order to meet the need for increased processing capacity, a stable investment climate is necessary and difficulties rising from the fact that the costs and benefits appear in different parts of the supply chain must be overcome.

Suggested topics for development and further research are identification of ores that are possible to beneficiate to DR grade at a competitive cost and methods to establish the actual quality of purchased scrap and its potential for upgrade.

Acknowledgements The authors are grateful to Mr Anton Löf, RMG Consultants; Mr Jan-Olov Wikström; Dr Roger Selin; Mr Magnus Tottie and Mr Björn Keskitalo of LKAB and Mr Heiner Guschall and Mr Thomas Schanz of Sicon GmbH for data support and fruitful discussions.

Funding Open access funding provided by Royal Institute of Technology.

Data availability The input and output data from RAWMATMIX® are available on request.

Code availability RAWMATMIX® is a commercial software from Kobolde \& Partners AB that is available as a cloud service under licence agreements.

\section{Declarations}

Conflict of interest The authors declare no competing interests.

Open Access This article is licensed under a Creative Commons Attribution 4.0 International License, which permits use, sharing, adaptation, distribution and reproduction in any medium or format, as long as you give appropriate credit to the original author(s) and the source, provide a link to the Creative Commons licence, and indicate if changes were made. The images or other third party material in this article are included in the article's Creative Commons licence, unless indicated otherwise in a credit line to the material. If material is not included in the article's Creative Commons licence and your intended use is not permitted by statutory regulation or exceeds the permitted use, you will need to obtain permission directly from the copyright holder. To view a copy of this licence, visit http://creativecommons.org/licenses/by/4.0/.

\section{References}

Acatech - Deutsche Akademie der Technikwissenschaften (2018) CCU und CCS - Bausteine für den Klimaschutz in der Industrie Analyse, Handlungsoptionen und Empfehlungen. ISSN 2192-6166 (in German)

Arzpeyma N, Gyllenram R (2021) RAWMATMIX® Standard materials and energy sources 20210110, System documentation. Kobolde \& Partners AB. https://doi.org/10.13140/RG.2.2.32940.69760 
Arzpeyma N, Gyllenram R, Jönsson PG (2020) Development of a mass and energy balance model and its application for HBI charged EAFs. Metals 10(3):311. https://doi.org/10.3390/met10030311

Barrington C (2020) The Global HBI/DRI Market: outlook for seaborne DR Grade pellet supply. IIMA, International Iron metallics Association, PowerPoint presentation at Fastmarkets Virtual Conference: Middle East Iron \& Steel 2020, December 14-17 2020

Boom R, Steffen R (2001) Recycling of scrap for high quality steel products. Steel Res 72:91-96. https://doi.org/10.1002/srin. 200100090

Cavaliere P (2019) Clean Ironmaking and Steelmaking Processes, Efficient Technologies for Greenhouse Emissions Abatement. Springer. https://doi.org/10.1007/978-3-030-21209-4

Chaigneau R (2015) Rio Tinto-IOC operations, DR production and product. Rio Tinto, PowerPoint presentation at Metal Bulletin 3:rd World DRI \& Pellet Congress, 2-4 March 2015, AbuDhabi, UAE, Available online: https://www.metalbulletin.com/events/download. ashx/document/speaker/7663/a0ID000000X0kBqMAJ/ Presentation. Accessed 16 Sep 2020

Chapa L, Duarte P (2001) The importance of iron ores in direct reduction, HYL Technology Division - HYLSAMEX, S.A. de C.V. CVRD Seminar, Brazil, September 2001. Available online: https://www. energiron.com/wpcontent/uploads/2019/05/2001-The-Importanceof-Iron-Ores-in-Direct-Reduction.pdf. Accessed 16 Sep 2020

EC (2019) The European Green Deal. Communication from The Commission to The European Parliament, The European Council, The Council, The European Economic and Social Committee and The Committee of The Regions, COM/2019/640 final, Available online: https://eur-lex.europa.eu/legal-content/EN/TXT/?uri= CELEX\%3A52019DC0640 (accessed on 2020-09-16)

Gyllenram R, Arzpeyma N (2021) RAWMATMIX® DRI-optionheuristic DR-shaft approach 20210110, System documentation. Kobolde \& Partners AB. https://doi.org/10.13140/RG.2.2.17002. 34243

Gyllenram R, Wei W, Jönsson P G (2015a) Raw material assessment for electric arc furnace steelmaking. Proceedings of the 6 th International Congress on the Science and Technology of Steelmaking, ICS 2015, Chinese Society for Metals, 2015, p 288-292

Gyllenram R, Sikström P, Hahne R, Tottie M (2015b) Classification of DRI/HBI based on the performance in the EAF. A help for steelmaker's procurement of metallics. Proceedings / METEC \& 2nd ESTAD 2015, European Steel Technology and Application Days : Düsseldorf, Germany, CCD Congress Center Düsseldorf, 15 - 19 June 2015

Gyllenram R, Wei W, Guschall H, Schanz T, Keskitalo B, Tottie M (2020) Not only the iron content, how scrap upgrading and ore beneficiation affect the value of scrap and DRI. PowerPoint presentation at AIST Scrap Supplements and Alternative Ironmaking 8, Orlando, USA, March 2-4 2020

Hooey L, Riesbeck J, Wikström J-O, Björkman B (2014) Role of ferrous raw materials in the energy efficiency of integrated steelmaking. ISIJ Int 54(3):596-604. https://doi.org/10.2355/isijinternational.54.596

IEA International Energy Agancy (2020) Iron and steel technology roadmap, towards more sustainable steelmaking. Part of the Energy Technology Perspectives Series, October 2020. https:// www.iea.org/reports/iron-and-steel-technology-roadmap (accessed October 2020)

Kirschen M (2021) Visualization of slag data for efficient monitoring and improvement of steelmaking slag operation in electric arc furnaces, with a focus on $\mathrm{MgO}$ saturation. Metals 11:17. https://doi.org/10. 3390/met11010017

Löf A, Löf O (2020) This Year's Iron Ore Report Looks Much Better Than Many Expected, High prices and a tight market could extend the rally well into 2022. Engineering \& Mining Journal October 2020 p 28-33, available on-line at: https://www.e-mj.com/ flipbooks/november-2020/

Midrex technologies Inc (2018) World Direct Reduction Statistics. Available online: https:/www.midrex.com/wp-content/uploads/Midrex STATSbookprint_2018Final-1.pdf (accessed on 2020-09-16)

Quader MA, Shamsuddin A, Dawal SZ, Nukman Y (2016) Present needs, recent progress and future trends of energy-efficient Ultra-Low Carbon Dioxide $\left(\mathrm{CO}_{2}\right)$ Steelmaking (ULCOS) program. Renew Sust Energ Rev 55:537-549 dx.doi.org. https://doi.org/10.1016/j. rser.2015.10.101

Rutschman M, Tottie M (2018) Value-in-use of pellets for DR. SME Annual Conference \& Expo, Minneapolis. PowerPoint presentation

Selin R (1987) The role of phosphorus, vanadium and slag forming oxides in direct reduction based steelmaking. Ph.D. Thesis, Royal Institute of Technology, Stockholm, Sweden.

Selin R (1991) Studies on MgO solubility in complex steelmaking slags in equilibrium with liquid iron and distribution of phosphorus and vanadium between slag and metal at $\mathrm{MgO}$ saturation. I: Reference system $\mathrm{CaO}-\mathrm{FeO} *-\mathrm{MgO}$ sat- $\mathrm{SiO}_{2}$. Scandinavian Journal of Metallurgy 20: 279-299. Part II. The total system including $\mathrm{Al}_{2} \mathrm{O}_{3}$ , $\mathrm{SiO}_{2}, \mathrm{TiO}_{2}$, ibid. 1991, 20: pp 318 - 328 .

Song S, Zhao J, Pistorius PC (2020) MgO refractory attack by transient non-saturated EAF slag. Metall Mater Trans B Process Metall Mater Process Sci 51:891-897. https://doi.org/10.1007/s11663-02001788-x

Suito H, Inoue R, Takada M (1981) Phosphorus distribution between liquid iron and $\mathrm{MgO}$-saturated slags of the system $\mathrm{CaO}-\mathrm{MgO}-$ $\mathrm{FeOx}-\mathrm{SiO}_{2}$. Trans Iron Steel Inst Japan 21(1981):250-259

Tanzer SE, Blok K, Ramírez A (2020) Can bioenergy with carbon capture and storage result in carbon negative steel? Int J Greenh Gas Control 100. https://doi.org/10.1016/j.ijggc.2020.103104

Turcotte S, Marquis H, Dancy T (1985) The use of direct reduced iron in the electric arc furnace. In: Custer C (ed) Electric furnace steelmaking, AIME, Iron Steel Society, Chapter 10 p 115-126

World Steel Association (2018), Steel's contribution to a low carbon future and climate resilient societies-worldsteel position paper. Available online: https://www.worldsteel.org/en/dam/jcr:66fed386fd0b-485e-aa23-b8a5e7533435/Position paper climate 2018.pdf (accessed on 2020-09-16)

World Steel Association (2020), 2020 world steel in figures. Available online: https://www.worldsteel.org/en/dam/jcr:f7982217-cfde-4fdc8 ba0-795ed 807 f513/World\%2520Steel\%2520in\%2520Figures $\%$ 25202020i.pdf (accessed on 2020-09-16)

Xiong D, Lu L, Holmes R J (2015) Developments in the physical separation of iron ore: magnetic separation. In: $\mathrm{Lu} \mathrm{L}(\mathrm{ed})$ Iron ore mineralogy, processing and environmental sustainability Woodhead Publishing Series in Metals and Surface Engineering: Number 66, Chapter 9, pp 283-307

Publisher's note Springer Nature remains neutral with regard to jurisdictional claims in published maps and institutional affiliations. 